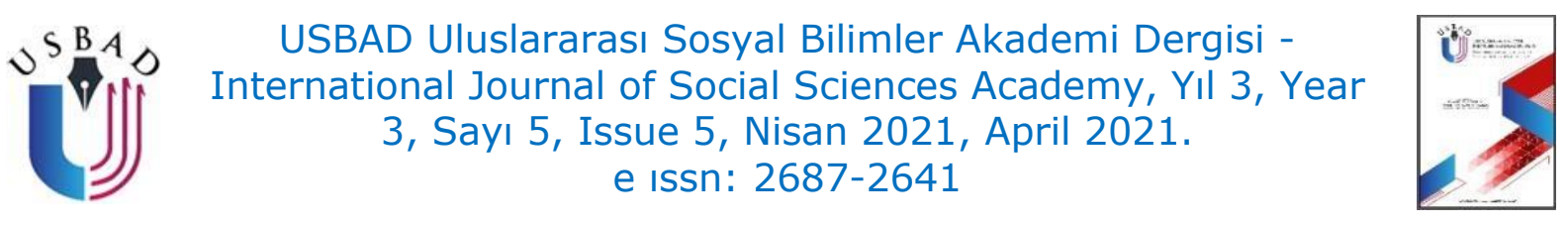

\title{
TÜRKİYE CUMHURİYETİ'NİN İNŞA SÜRECİNDE ÜST KİMLİK ÇIKMAZI
}

\author{
SUPRA-INDENTITY IMPASSE IN THE PROCESS OF BUILDING THE \\ REPUBLIC OF TURKEY
}

\begin{abstract}
Mustafa KOL
Yüksek Lisans Öğrencisi, Sakarya Üniversitesi, Sosyal Bilimler Enstitüsü, Sosyoloji Bölümü, Sakarya/Türkiye.

Graduate Student, Sakarya University, Institute of Social Sciences, Department of Sociology, Sakarya/Turkey. sosyologbeyden@gmail.com

ORCID ID: $0000-0002-0418-2740$

Makale bilgisi | Article Information

DOI: $10.47994 /$ usbad.857464

Makale Türü / Article Type: Araştırma Makalesi / Research Article

Geliş Tarihi / Date Received: 10.01.2021

Kabul Tarihi / Date Accepted: 13.03.2021

Yayın Tarihi / Date Published: 20.04.2021

Yayın Sezonu / Pub Date Season: Nisan / April
\end{abstract}

Bu Makaleye Atıf İçin / To Cite This Article: Kol, M. (2021). Türkiye Cumhuriyeti'nin İnşa Sürecinde Üst Kimlik Çıkmazı. USBAD Uluslararası Sosyal Bilimler Akademi Dergisi 3(5), 643-683.

Intihal: Bu makale intihal.net yazılımınca taranmıştır. İntihal tespit edilmemiştir. Plagiarism: This article has been scanned by intihal.net. No plagiarism detected.

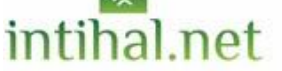

İletişim: Web: https://dergipark.org.tr/tr/pub/usbad mail: usbaddergi@gmail.com 
Öz: Kimlik konusunun kapsamı çok geniştir. Türk kimliği, milli kimlik, resmi kimlik ve kimlik dönüşümü üzerine birçok araştırma yapılmıştır. Çalışmanın önemini, Türkiye Cumhuriyeti'nin kuruluş süreci öncesinden başlayan ve kuruluş sonrası devam eden kimlik tartışmaları üzerine yoğunlaşarak, dönemin sosyal, siyasal ve ekonomik şartları dahilinde, araştırma gerçekleştirilmiştir. Ulus-devlet inşa sürecinde, resmi kimlik oluşturma çabaları ve bu doğrultuda geleneksel ideolojilerin reddi ortaya çıkartılarak, kimliğin dönüşümü incelenmiştir. Araştırma, 1839'da Tanzimat Fermanıyla başlayan batılılaşma çabaları, demokratikleşme girişimleri ve kimlik algısı üzerine etkilerinden, Atatürk'ün ölümü 1938'e kadar geçen süreç kapsamında ele alınan dönem sınırlandırılmıştır. Belirlenen dönemin karakteristik özellikleri dışına çıkılmadan kimlik konusunu incelenmektedir. Çalışmanın yöntemi için "Dökümantasyon Metodu" seçilmiş, konular bu yöntem sayesinde araştırımıştır. Kısaca konular; Türkiye Cumhuriyeti'nin kuruluş sürecinde üst kimlik inşası, inşa sürecine yardımcı batılılaşma çabaları, İslâm kimliğinin devlet için ideal kimlik görülmemesi, Osmanlı Devleti'ni şekillendiren, kontrol altına alan İslâm dini, yeni rejimle birlikte devlet kontrolü altına alınması, toplumun algısal kimliğindeki değişimler ve Cumhuriyet ideolojisinin benimsetmek istediği kimlik görüşü geniş kapsamlı incelenmiştir.

Anahtar Kelimeler: Kimlik, Üst Kimlik, Kimlik Dönüşümü, Milli Kimlik, Türk Kimliği, Batılılaşma, Ulus Devlet İnşası

Abstract: The extent of identity issue is very wide. Many studies have been conducted on issues related to Turkish identity, national identity, official identity and identity transformation. By focusing on identity building in the Republic of Turkey, a work was conducted based on the conditions of the period. In the process of nation-state building, the transformation of identity has been examined by revealing the efforts to form an official identity and the rejection of traditional ideologies in this direction. The study has been limited within the framework of westernization efforts, democratization attempts, effects on identity perception that started with the 1839 Tanzimat Edict, and innovations made until 1938, until Atatürk's death. The issue of identity is examined on the characteristic features of this period. The method of the study contains using "Documentation Method". Republic of Turkey, identity building, westernization efforts, the fact that the Islamic identity cannot be official identity required for the nation, Islam that shaped and controlled the Ottoman State which later was controlled by the Republican state, the transformation of identity perception of the society, and the perception of identity adopted by the Republican ideology has been examined.

Keywords: Identity, Supra Identity, Identity Transformation, National Identity, Turkish Identity, Westernization, Nation State Building

\section{GİRİ̧̧}

Kimlik, en genel anlamıyla ayrışma ve bütünleşme girişimidir. Kim olduğumuz, nereden geldiğimiz, kökenimiz gibi soruların cevabını bulmak 
aidiyet hissi için önemlidir. Kimlik, insanın kendisini ifade etme ve çevresine tanıtmak için kullanılan bir kavramdır. İnsanoğlu tarihsel süreçte nereden geldiğini ve nereye gideceğini, yaşadığı toplumda kendisini nerede konumlandırdığını ve kim olduğunu tarih boyunca sorgulamıştır. İnsanın yaratılışı gereği sosyalleşme ihtiyacı olan bir varlık olduğundan, insan kendisini tanımlamak için yaşadığı topluluğun içinde bir bağ kurabilmek için kimliğini belirlemek istemektedir. Diğer toplumlardan onları ayıran özellikleri, farklılıkları neticesinde diğer toplumlardan ayrışmayı, yaşadığı toplum içindeki; kültür, yaşam tarzları, gelenek görenek uyumları gibi benzer özelliklere göre bütünleşmeye itmiştir. İnsanoğlu ilkel dönemlerden itibaren yaşadıkları toplumlarda belli birtakım statüler içerisinde yer almış, toplumun genel ortak özelliklere sağıp olsalar dahi kendi içlerinde de ayrışmalar yaşamışlardır (Altunoğlu, 2009).

İnsanlar; cinsiyet, ten rengi ve inançları gibi birçok farklı unsurlar çerçevesinde toplumlarında konumlandırılmıştır. Bu süreç tarih boyunca farklı adlandırmalar altında devam etmiştir. İnsanların bu unsurları göz önünde bulundurularak bireysellikten, gruplaşmaya bunun neticesinde kendisini konumlandırdığı yere göre, üzerine düşen sorumlulukları yerine getirmeye çabalamışlardır, yani aidiyet hissinin gereksinimlerini karşılamışlardır. Türkiye Cumhuriyeti inşa sürecinde üst kimlik çıkmazı adlı bu çalışma, kimlik kavramının tarihsel süreci özellikleri, toplumsal kimlik, kimliği inşa eden unsurlar, Türk kimliği, Milli kimlik, İslâm kimliği, Batı kimliği, Osmanlı Devleti'nin son dönemlerinden Cumhuriyetin ilk çeyreğine kadar kimlik algısı üzerine gerçekleşmiş değişimler bağlamında konu incelemeye alınmıştır. Cumhuriyetin ilanından itibaren değişen üst kimlik algısı, batılılaşma girişimleri, toplumun değiştirilip dönüştürülmesi, devlet eliyle bir kimliğin dayatılması, toplum tarafından tam olarak benimsenmemiştir. Kimlik inşa süreci tamamen cumhuriyetin ilanıyla başladı demek doğru olmayacaktır. Osmanlı Devleti'nde kimlik inşa süreci Tanzimat Dönemi hatta daha eski süreçlere kadar uzanmaktadır. Kimlik algısı Tanzimat döneminde farklılaşmaya, değişmeye başlamış Cumhuriyetin ilanından sonra gerçekleşen inkılaplarla birlikte yeniden inşa edilmesi gerek görüşünün ortaya çıktığı bir sürece dönüşmüştür. 1839 tarihinde Gülhane meydanında okunan Tanzimat Fermanıyla hukuk alanında ve yönetimde değişlikler gerçekleştirilmeye çalışılmıştır. Tanzimat Fermanı daha sonra devlet yapısında önemli etkiye sahip olmasa da toplum yapısında hukuki, sosyal ve siyasal alanlara yönelik farklı bakış açıları oluşturması yönüyle önemlidir (Gülalp, 2003).

Tanzimat Fermanının toplumsal yapı üzerindeki etkisinin ardından I. Meşrutiyet Dönemi de kimlik algısının dönüşümünde etkili olmuştur. II. 
Abdülhamid tarafından 1876 tarihinde ilan edilen Kanuni Esasi'yle ilk defa anayasal bir süreç başlamıştır. Padişahın bu süreçte yürütmenin başında bulunması ve yasamada gücü elinde bulundurmasına rağmen, toplumda mevcut düzen üzerine görüşlerin değişmesine, şekillenmesine neden olmuştur. I. Meşrutiyet'le başlayan süreç, 1908 tarihinde Genç Türklerin baskısıyla, Kanuni Esasi yeniden kabulü sağlanmıştır. 31 Mart olaylarının ardından II. Abdülhamid tahtan indirilmiş ve padişahın yetkilerinde sınırlandırma sağlanmış, bu sayede meclisin yetkileri arttırılmıştır. Bu süreç daha sonra Cumhuriyetin ilanına varacak süreçte, farklılaşmanın demokratikleşme sürecinin başlaması olarak görülebilir (İnceoğlu, 2009).

Osmanlıcılık, İslâmcılık, Türkçülük gibi ideolojiler o zamanın belli birtakım aydınları tarafından Batıcılık ideolojisi gibi daha gerçekçi görülmeseler de toplumsal kimlik oluşumunda etkili görüşler olarak kabul edilmişlerdir.

Toplumsal değişme, Cumhuriyetin ilanı sonrası ivme kazanmıştır. Osmanlı Devleti'nden kalan toplumsal yapı değiştirilmeye, Batıdan alınan siyası yapı ve inkılaplarla, kalıcı farklılaşmalar halka uygulanmaya çalışıldı. İnkılaplarla, eski işlevini kaybetmiş yapıların yerine Batıcılık ideolojisi önderliğinde bize yabancı olan Batı tipi yenilikler, düşünceler ortaya koyulmuştur. Yeni devlet, Osmanlı Devleti'nin yıkılmasına neden olarak gösterilen teknoloji de geri kalma düşüncesi neticesinde, yeni devletin dünya teknolojisine hakım olan modern, muasır bir devlet olması planlanmıştır. Elbette bu süreç hayli zor ve meşakkatli bir süreç olmuş ve olmaktadır.

Yeni rejimle Batılılaşma hareketleri hızlı olsa da yapılan yenilikler rast gele değil de oldukça sistematik bir şekilde gerçekleştirilmiştir. Bu dönemde halk ile devlet yapısı bütünsel olarak değişip dönüşerek modern Türkiye'nin temelleri atılmıştır. Milli kimlik temelleri bu dönemde atılması, halkın milli beraberlik göstermesi, ulu önder Atatürk'ün liderliğinde kurtuluş savaşının başlatılması, toplumun milli kimlik olarak Türk kimliğini benimsemesi olumlu bir olgudur. Bu dönemde Ulu önder Mustafa Kemal Atatürk'ün liderliğinde kazanılan başarılarla birlikte, milli kimlik pekişmiştir. Ulusal kimlik, tek vücut halinde kurtuluş savaşını kazanan, dünyaya örnek teşkil eden bir kenetlenme ve direniş sergilenmiştir. Ulusal kimliğin oluşmasına, millet olarak bütünsel hareket etmemiz gösterilebilir. Cumhuriyet'in inşa sürecinde kimlik değişmesi, 1 . Dünya savaşının olumsuz neticelenmesi, bu olumsuzluğun temeli olan modern teknolojiye sahip Batı medeniyeti, Kurtuluş Savaşına girmemiz, toplumsal değişimin yeni kimlik arayışının kaynakları olarak gösterilebilir (Şevkli, 2009). 


\section{KAVRAMSAL ÇERÇEVE}

\subsection{Kimlik}

Kimlik kavramı, benzerliği ve sürekliliği içeren Latince, idem kökünden türetilmiştir. Türkçede kimlik kavramı, "kim" soru kökünden türetilmiş ve aynı şekilde zorunlu bir mensubiyet ya da aidiyet, benzer olmayı, tek olmayı, kısaca birleştiren ve ayıran özellikleri tanımlayan, anlamına gelmektedir (Aydoğdu, 2004: 117). "Kimlik, insana gündelik hayata uyumu kolaylaştıran bir sosyal çevre, bilişsel harita sunar" (Bostancl, 2005'den akt. Altunoğlu, 2009: 110). Kimlik, tarihsel süreç içerisinde değişime uğrayan bir kavram olarak karşımıza çıkmaktadır. Toplumlar kendi anlam dünyalarına göre kavramların manalarını yorumlarlar. Bizlerinde ele aldığı kavramlar, tarihsel süreçte yaşamış olduğumuz değişimlere paralel şekillenmektedir.

Türk Dil Kurumunun, Türkçe sözlüğünde kimlik kavramı "Toplumsal bir varlık olarak insana özgü olan belirtili nitelik ve özelliklerle, birinin belirli bir kimse olmasını sağlayan şartların bütünü" olarak ifade edilir (Tdk.com). Kimlik, bir birliktelik sağlayan ortak, benzer özellikleri tamamının içerir. Öte yandan ayrışmalarda kimlikte aranan özelliklerin birbirleriyle uluşmamasından doğar. Yani kimlik, kendisi dışındaki, diğerleriyle ilişkiyi ve iletişimi mümkün kılan, gündelik yaşamın olağanlığı içerisinde, tercihlerde bulunmamıza yardımcı olan ve insana hayatın zorluklarına karşı güç veren, yaşam içerisinde neyin iyi ya da neyin kötü olduğunu anlamamızı sağlayan bir bakış açısıdır. Ayrıca kimlik haz ve arzulara, verdiğimiz karalara, gelecekten beklentilerimize etki eden, kişiyi yalnızlıktan kurtulmasını sağlayan bir hayat ufkudur (Altunoğlu, 2009: 110). Kimlik üzerine tartışmalar kolay kolay neticelenmez, kimlik farklı alanlarda incelenmekte, benlikle arasındaki benzerlikleri ve farklıkları belirlenmeye çalışılmaktadır. Her ikisinde de kişinin kendisini algılaması ortak noktayken, benliğin kolay değişmesi, kimliğin daha istikrarlı olma özelliği en belirgin fark olarak söylenebilir.

Kimlik, kavramı günümüzde en çok tartışılan, konuların başında yer almaktadır. Kimlik konusu ülke politikalarını meşgul eden önemli bir sosyal bilimler kavramı olarak ele alır. Kimlik kavramı günümüzde başta sosyoloji, siyasal bilimler, sosyal psikoloji, edebiyat, felsefe, antropoloji gibi birçok bilimi ilgilendiren temel bir kavram olarak düşünülmektedir. Bu kadar disiplinin kimlik kavramına kendi bakış açılarıyla yaklaşma çabaları, kimlik konusunun teorik çerçevesinin gelişmesine olumlu katkı sağlamaktadır. Bireyin kimliğini çözümleyebilmesi için asıl soru "ben ve benim dışımdakilerin kim?" olduklarıdır. Bireylerin ve toplumların birbirlerinden 
ayrışıp sınıflandırmaları bu soruya "ben ve benim dışımdakiler kim?" verilen cevaplarla doğrudan ilişkindir. İnsanlar daima benzerlik ve farklılıklar açısından kategorize ederek kendisini bir noktada konumlandırır. Bu sayede insan nereye ait olduğunu daha iyi anlar ve kimliğini algılar. İşin özü kişinin kendini konumlandırdığı yeri tanımlamasına dayanır ve durduğu yerde kendinden olanları ve ötekilerini daha rahat görebilir (Karakaş, 2015: 93).

Toplum olmadan kendimizi nasıl konumlandıracağımızı bilemeyiz onun içindir ki, yaşam alanlarımızı toplumun içerisinde almış olduğumuz kimlikler, görevler ve sorumluluklar şekillendirilir. Toplum eğer keskin bir biçimde ayrışmış ise o halde önemli husus kimliklerimize düşer, eğer çoğunluğun ve iktidarın kimliğiyle kimliğiniz aynı ise özgür olma olasıllı̆ınız artacaktır. Tersi bir durumda sosyal yapı içerisinde hor görülebilir ve özgürlüklerden ya da daha iyi bir ifadeyle devlet imkanlarından eşit yararlanma olasılığınız azalacaktır. Tabii bu bir varsayımdır. Devlet yönetiminin gücünü aldığı kesimin daha fazla faydalandığıysa varsayım değil gerçektir.

Kimlik tanımı sadece bireye bağlı toplumdan bağımsız bir olgu değildir. Bu bağlamda sosyal kimlik teorisinin merkezinde, her daim gruplar ve grup ilişkileri yer alır. Psikoloji de birey ya da kişilik, kimlik algısında temel bir yıkılmaya neden olmuştur. Öteki grupların kimliklerine göre yer konumlanmamız kimlik algısı şekillenir. Üyesi olunan grubun diğer gruplar arasındaki ilişkiler sosyal kimliği temellendirir (Bilgin, 2003'ten akt. Altunoğlu, 2009: 12). Kimlik kavramının hissettirdikleri, toplumda ne kadar birey ve grup tarafından benimsenmesi önemlidir. Çünkü sosyal kimlikler, grup yapılarını belirler ve gruplar insanların, güven ihtiyaçlarını karşılamaya yardımcı olurlar. Kendi grubumuzun dışındaki gruplar, bizim için kimi zaman tehlike teşkil edebilir. Bu kestirilemez, öteki gruplar hem bizi kendi grup içinde kenetler hem de kimlik algımızı şekillendirmeyi sağlar. Gruplar arası etkileşim kadar, bireysel özellikler de kimlik kavramını inşa etmektedir. Bu konuda en tanınmış düşünürlerden birisi George Herbert Mead'tir. Sosyal kimlik kavramı üzerine Herbert Mead'in "sosyal benlik" adlı kavramsallaştırması, eski anlamlarının yerine yeni anlamlar yükleyerek, kimlik kavramını yeniden üretmiştir. Bireysel kimliği karşılayan, I, (ben) ve sosyal kimliği karşılayan me (beni/ana) kullanarak kimliği ikiye ayırmıştır. İkisi arasındaki etkileşimden yola çıkarak, bireyin toplum ürünü olduğunu ifade eder. Sadece tek taraflı kalmayıp karşılıklı bir üretim gerçekleştiğini, toplumda bireyi ürettiğini ve bu durumun devamlı olduğunu söyler (Deschamps ve Devos, 1998'den akt. Altunoğlu, 2009: 50). Kimlik sadece toplum ve birey arasındaki ilişkinin ürünü değildir. Bireyin kimlik sorgusunda en önemli kaynak, ben nereden geliyorum, atalarım kim gibi 
tarihi geçmiş sorulardır. Bireyin kendisini konumlandırabilmesi için geçmişini bilmesi önemlidir. Eski tarihlere uzanan toplumsal ilişkiler geçmişte yaşanan çekişme ya da ticari ilişkimiz, yaşadığımız dönemde tutum ve davranışlarımızı etkiler. Diğer toplumlara karşı algımız, geçmişe paralel olarak artıp azalacaktır.

\subsection{Kimlik Dönüşümü}

Modernleşmeyle başlayan bireysel ve toplumsal etkileşim unsurlarının en etkili olanlarından biri kimlik algısıdır. Kimlik algısı, toplumsal ve bireysel anlam dünyalarının yeniden üretilmesi, inşa edilmesinde belirleyici referans sağlamaktadır. Çünkü kimlikler hem toplumsal hem de bireysel olarak üretilmekte, inşa edilmektedir. Bireye ve topluluğa, algısal düzeyde farklı anlam dünyaları sunan kimlikler, tanımlayıcı referanslarımız olarak işlev görürler. Kimlikler, yaşanmışlıklarımızın ve kendimizi konumlandırdığımız görüşlerden oluşur ama toplumsal etkileşim devam ettiği sürece, yaşanmışlıklarımızın ve kendimizi konumlandırdığımız görüşlerin toplamından daha fazlası haline gelirler. Kimlikte değişim süreklidir, toplumun değişkenliklerine bağlı olarak her değişimle birlikte yeniden kimlik inşa edilir. Toplumsal ve tarihsel olguların etkin olduğu kimliğin algılanma biçimi, bireyin ve toplumun değişimine paralel bir şekilde değişir (Karakaş, 2013: 2).

Modern dönem öncesi kimlik algısı üzerine etkenler günümüzden farklıdır. 19. yüzyıl öncesi insanların kimlikler üzerinden ayrışması üç kategoride belirlenmiştir. Ülke ya da mekân ve cinsiyet, sosyal ve ekonomik koşullar geleneksel dönemde kimliklendirme araçlarındandır. Bunların içerisinde en keskin olanı cinsiyete dayalı kimliklerdir. Modern ulus-devlete geçilmeyle birlikte, cinsiyete göre bir kimliklendirme, ötekileştirme azalmıştır, ama toplumsal yaşantı içerisinde halan daha cinsiyete dayalı kimliklendirme mevcuttur. Mekân ya da ülke toprağı üzerinden kimliklendirme sadece geleneksel döneme değil günümüzde, ulus devlet üzerinde etkilidir. Orta Çağ Avrupa'sında toplumsal sınıfların oluşumu, toplum içinde asker, soylu ya da köylü gibi kimlikler ortaya çıkmıştır (Karakaş, 2015: 98-99).

Sosyologların bahsettiği iki tür kimlikten genel olarak söz edilir. Bunlardan birincisi sosyal kimlik, ikincisi de bireysel kimliktir. Bu iki ayrımın birbiri üzerindeki etkileri araştırılır. Sosyal kimlik bir kişiye ya da gruba başkaları tarafından yüklenen nitelikleri gösterir. Bu nitelikler o toplumun içinde bulunan kişilerin kim olduğunu belirten göstergelerdir. Toplumun içinde yer alan bireyler birçok özelliklerden oluşan sosyal kimliklere sahiptir. Bireysel kimliğin de temelinde duygusal algı ve dış dünyayla sürekli 
etkileşimi olan kimliği ifade eder. Sosyal kimlik ve bireysel kimliğin birbirlerinden ayrı olmadığı, etkileşim içerisinde oldukları bilinir (Avcıoğlu, 2011: 362).

Toplumların, kimlik algıları kendi toplumsal değerler ve sosyal normlar üzerinden oluşturulur. Bu yapısal kimlikler, değişmeye paralel bir şekilde sürekli dönüşüme uğrar ve en önemli dönüşüm nedenleri arasında teknolojiyle birlikte modernleşme ve post modernleşme yer alır. Avrupa'da ortaya çıkan modernleşme ve post modernleşmenin isteği üzerine uluslaşma ve bu bağlamda, ulusu kapsayıcı, üst kimlik ya da milli kimlik çatısı altında zamanla ulusal kimliğe bağlanan onunla bir bütünlük arz eden kimlikler yer alır. Kişinin kendisi ve toplumuyla ilgili kimlik algısı modernleşmenin sunduğu, olanaklarla yeniden inşa edilmiştir. Kimlik dönüşümü normal şartlarda yavaş gerçekleşmektedir, ama dış etkenlere maruz kaldıkça kendisini dış değişkenlerin etki kuvvetine göre değişimi hızlanabilir. Doğal bir süreçten çıkarılması ve değişim hızının artması aslında savunma, ihtiyacından kaynaklanabilir. Bir kimlik eğer üst kimlik olma çabalarındaysa, o zaman kimliğin gerekli koşulları, esnek hale getirebilir. 0 halde kimlik savunma ihtiyacından daha güçlü bir noktaya gelebilmek için yavaş olan hızını arttırır ve değişir (Hall, 1998'den akt. Avcıoğlu, 2011: 363). Bu bağlamda geleneksel toplumlardan, modern toplumlara geçişte bireysel kimliğin değişimi incelenirse daha önceki kimlik oluşumunu yönlendiren sabit etkenlerden bir uzaklaşma olduğunu görülür. Bir zamanlar insanların kimlikleri geniş toplumsal grupların üyeliğine dayanmaktaydı, bir sınıf ya da milliyete bağlı olurken artık çok yönlü ve daha az istikrarlıdır.

Kentsel büyüme, sanayileşme ve önceki toplumsal oluşumların incelmesi geleneksel kuralların etkisine zayıflatmıştır. Modernleşmeyle birlikte insanlar geçmişin sıkıcı örülmüş, görece türdeş olan kalıplardan, katı bir biçimde kuşaklar boyu aktarıldığı toplumlardan, uzaklaşmıştır. 21. yüzyıl dünyasında kendimizi ve kendi kimliğimizi yaratmak için geçmişte olmayan fırsatlara sahip olunduğu inancı, toplumları geleneksel yol işaretlerinden uzaklaşmaya onları terk etmeye itmiştir. Modernleşen toplumsal dünyada karşımıza, kim olacağımız ve ne yapacağımız konusunda çok fazla seçeneklerin olduğu söylenmektedir. Bireycilik bilincine sahip ve bunun farkında olan insanlar artık kendi kimliğini sürekli olarak inşa edecekleri inancındadırlar. Kimlik inşası sürekli ve bitmeyen bir süreç olarak görülür. Zamanın şartlarına göre inşa süreci hızlanıp yavaşlayabileceğini bilmemiz gerekir. Kimliklerin gücü aslında ne kadar çok kişi tarafından söylenmesine tanımlamada kullanmasına bağlı olmayıp, kimlik özelliklerinin toplumsal davranışlarında düşüncelerde ne ölçüde varlığını sürdürmesinden 
almaktadır. Davranış ve düşüncenin temelinde yer alan kimlik güçlüdür (Avcıoğlu, 2011: 364).

\subsection{Milli Kimlik}

Millet sözcüğünün İngilizce karşılığı Notion'dır. Notion sözcüğü Türkçeye ulus olarak çevrilir. Millet ve milliyetçilik kavramlarıysa tam olarak nation ve nationalism sözcüklerinin anlamlarını karşılamazlar. Milli kimlik, bir milletin kendine has düşünüş ve bu neticede yaşamında bu düşünceyi pratiklere dökebilmesiyle ilişkilidir. Dil, töre ve gelenekleri, toplumsal değer yargıları ve kurallarıyla oluşan özellikler bütünü olarak milli hüviyet şeklinde somutlaştırılmıştır (Tdk.com). Bireysel ve toplumsal kimlikleri oluşturan unsurun kültür olduğu, kültürlerinde kendine has olmaları nedeniyle kendi bütünlükleri içinde kültürel kimlikleri meydana getirdiği söylenebilir, dolayısıyla bireysel kimlikler; kültürel kimliklerinin, sosyal normlarının bireylere aktarılmasıdır. O halde kültürel kimliğini milli kimlik olarak kabul edersek, milli kimliği tam olarak anlamamız gerekir. Milli kimliği oluşturan beş, ana kaynaktan söz edilir. Sırasıyla şu şekilde sıralanır.

"a) bir tarihi süreç içinden süzülüp gelen, tabii gelişmelerle şekillenen gelenek ve göreneklerin yol açtığı değer norm ve sosyal kontrol unsurları, b) dini hayatın inançların sebep olduğu değer norm ve sosyal kontrol unsurları, c) alay edilmek, gülünç düşme korkusunun doğurduğu; değer, norm ve sosyal kontrol unsurları, d) kanun, tüzük ve yönetmeliklerin telkin ettiği norm ve sosyal kontrol unsurları, e) yerli kültürün dışından gelen bazen iktibas edilen bazen bünyeye uygun hale getirilen değer norm ve sosyal kontrol unsurları" (Tural, 1992'den akt. Avcıoğlu, 2011: 363).

Türkiye'de millet, ulus ve milliyetçilik, ulusçulukla ilgili akademik literatürde var olan kavramlar, tam olarak birbirlerinden ayrıştırılmada yetersiz kalındığından dolayı ulus, etnisite ve ırk kavramları birbirinin yerine kullanılır hale gelmiştir. Bende araştırdığım kaynaklarda kullanıldığı gibi millet, ulus ya da milliyetçilik, ulusçuluk kavramlarını kullanacağım. Milliyetçilik kavramının yönelik tanımlamalar farklılık gösterir. Milliyetçilik kavramı, 18. yüzyıldan günümüze kadar, üslendiği tarihi ve siyasi gerçekliği yansıtan birçok anlamı içermektedir. Kullanımına ilk kez Alman filozof Johann Gottfired Herder'in 18. yüzyııın sonlarındaki çalışmalarında rastlanan milliyetçilik terimi, genel dil kullanımına 19. yüzyılın ortalarında girmiştir. Milliyetçilik olarak ele alınır. Milliyetçilik, gerçek ya da değil, belirlenmiş bir ulusun gerekli olduğu koşuldur. Milliyetçilik, daha çok bir ideoloji ve ulus-devlete aittir. Ulus devletin intiyacı nedeniyle üretilmesi milliyetçiliği yapay bir olgu yapmaz, gerçekçiliği ve doğallığı ona inananlara 
bağlıdır. 19. yüzyılda Avrupa'da ortaya atılan düşüncede milli kimlikleri milliyetçilik düşünceleri doğurmuş, doğrudan etkilemiştir. Milliyetçiliğin temelli soyut kavramlara ya da geleneklere değil, içinde yaşadığı topluma yani millete dayanmaktadır. Millet olmasa milliyetçilik diye bir şey de herhalde olamazdı (Şevkli, 2009: 14). Milliyetçilik modernleşmeyle ulusdevlet üzerine inşa edilen bir kavramdır. 19. yüzyıldan bu yana dünya siyasi tarihindeki en derin, en inatçı ama yine de en ön görülen değişimi tetikleyen bir ideoloji olarak görülür. Milli Kimlik, kavramıysa, siyasi bir gruba aidiyet, olarak ifade edilmektedir. Ulus inşası ve bunun sonucu olarak ulus-devlet milliyetçiliğin siyasi uygulamasının temel görüşünü oluşturmaktadır (Alakel, 2011: 2). Milli Kimlik, insanın zihniyetini yeni düşüncelerle doldurup ve bilinci bir şekilde eyleme dönüştürmeyi tetikleyen siyası biçimli ideoloji yani sosyo-politik hareket olarak doğmuştur.

\subsection{Türk Kimliği}

Türk kimliğini açıklamaya Türk kavramın tarih sahnesine Osmanlı ya da Cumhuriyet'le çıkmış bir kavram değildir. Türk kelimesi Osmanlı İmparatorluğunun kendi ya da siyasi rejimini tanımlamak için ortaya çıkan bir kavram da değildir. Türk kavramı, Osmanlıda bir kimliği tanımlamak, bir kimliğe işaret manasında kullanılması ve Türk milliyetçiliğinin kullanımı, Avrupa'yla karşılıklı olan ilişkilere bağlı olarak ortaya çıktığı söylenebilir. Avrupa, doğuda güç kazanan Türkiye ve Türk kavramı Osmanlıları tanımlamak için kullanılmıştır. Anadolu medeniyetlerinde toplumsal kimlik en eski çağlardan beri daima çoğulcu niteliğe sahiptir. Malazgirt'te başlayan Anadolu'nun Müslümanlaşmasıyla birlikte ve Osmanlı Devleti döneminde de bu çoğulculuk korunmuştur. Önce modernleşme ve şimdi de küreselleşmeyle gelen Kapitalizm, kültürel ve bilişsel gruplaştırmalar, ben Türk'üm ben Laz'ım diye ayrıştırmalarını ortaya çıkmıştır. Ama Anadolu'nun yeniden Hristiyanlaşması için yoğunlaşan çalışmalara rağmen hala Anadolu bu dil, din, ırk ve yaşam tarzı zenginliğini oluşturan çoğulcu yapısını korumaktadır.

Türk kimliğini iyi bir şekilde anlayabilmemiz için Türk tarihini incelememiz gerekir. Türk tarihi ilk evresi bozkırsal bölgelere dayanmaktadır. İnsanın, tabiatın kuvvetlerine sahip olması tabiata hâkim olması, eski çağlarda yani coğrafyanın insan üzerinde; yaşam, kültür, örf ve adetine gibi birçok unsura etki ettiği düşünülebilir. Buradan yola çıkarsak eski Türklerin yaşayış biçimi olan bozkırsal hayat, göçebe hayat, Türklerin günümüze yansıyan kimlik anlayışlarını, algı dünyalarını doğrudan etkilediği düşünülmektedir. Canlıların yaşadığı coğrafyada hayat koşulları, tabiattan faydalandığı şekilde devam eder. İklim koşulları da insan yapısına büyük etkisi bulunur. İnsanlar yaşadığı ortamın koşullarına göre hayat algısını 
belirler, beslenme çeşitleri, tarımsal gıdaların çeşitliliği, toprak yapısı algı dünyalarının şekillenmesini ve kuşaktan kuşağa aktarmamıza etki eden faktörlerdendir. Milletlerin, tarihsel süreç içerisinde kendi üstün olduğu dönemleri vurgulanmaktadır, ancak tarih içinde Türk milleti gerçek anlamında medeniyetlere katkıları ve otoriter üstünlük bakımından hep ileri bir seviyede olmuştur (Kafesoğlu, 1991: 201). Türk kavramının geçmişi çok eski tarihlere dayanmaktadır. Çin, Bizans ya da Arap kaynaklarına bakarsak Türklerin çok eski geçmişe ve geçmişinden gelen güçlü toplumsal ve askeri teşkilatlardan oluştukları gözlemlenmektedir.

\section{5. İslâm Kimliği}

İslâm kimliğinin dayandığı kaynaklar ikiye ayrılmaktadır, bunlar; kutsal kitabımız Kur'an ve Peygamberimiz Muhammed Mustafa (s.a.v.)'in sözü ve davranışlarını ifade eden sünnetleridir. Osmanlı Devleti'nde saltanatını sürdüğü altı yüz yıl boyunca İslâm'la özdeşleştirilmiş bir siyasal yapı hakimdir. Çoğunluğu Müslüman toplumdan oluşan Osmanlı Devleti'nde hem üst hem alt sınıflarını birlik ve beraberlik hissiyle bütünleştirecek kimlik, İslâm olarak görülmüş. Bu görüşün en büyük temsilcisi Sultan II. Abdülhamid olmuş ve İslâmcılık ideolojisinin en güçlü olduğu zaman ise II. Abdülhamid'in saltanat döneminin ikinci yarısında İslâmcılık ideolojisinin hızlanarak yayılması gerçekleşmiştir. II. Abdülhamid'in İslâmcılık görüşü bütün Müslümanları birleştirmekten daha çok İslâm'i imparatorluk düşüncesi çerçevesinde birleştirmektir. Ama tam olarak bütün Müslümanları tek bir bayrak altında toplayabilmek, uzak bir hedef olarak da görülebilir (İnceoğlu, 2009: 14).

İslâm, İslâmiyet ve Siyasal İslâm kavramları farklı alanları kapsar. İslâmiyet, İslâm peygamberinin Allah'ın emirleri doğrultusunda insanlara ilettiği ilahi mesajların bütünüdür. İnananların yaşadıkları toplumların ve ait hissettikleri tarihin etkisiyle dini emirlere uyma biçimidir. Siyasal İslâm ise İslâm'ı kabul eden toplumların, batı modernleşmesinin önünde oluşturduğu İslâm'dan daha çok İslâmiyet'e dayalı modernizmle etkileşimli düşünce ve eylemlerin bütünüdür. Kendilerini yeniden bir yapılandırmaya giderek, İslâmiyet'in asıl gayesine dönerek, yeniden üst kimlik olabileceği düşünülür. İslâmi hareketler modernizm ve demokrasi karşıtı görülmektedir. Bunların bu şekilde hem modernizm ve hem de demokrasi karşıtı görünmelerinin iki sebebi vardır. İlk sebep, devletin laiklik ilkesine dayanarak kurumlardan dinin çıkarılması, ikinci sebep ise İslâm dininin modernleşmeyle bağ kuramaması olarak, yani İslâm kimliğini benimsemiş ve yaşamlarına İslâm koşulları çerçevesinde gerçekleştiren kişilerin modern ve demokratik görülemediklerinden kaynaklandığı söylenir (Türk, 2015: 100-101). İslâm kimliği Osmanlı'nın son dönemlerinde batılılaşma süreciyle başlayan ve 
devlet yapısında İslâm kimliği algısı, kendisini hedef olarak gören Avrupa devletlerine karşı bir mücadele girişimidir. Burada söylemek istediğimiz Avrupa devletlerinin hem Osmanlı'yı hem de İslâm dini üzerine saldıracağı görüşüyle kendilerine koruma amacıyla İslâm kimliği çatısı altında Osmanlı Devleti'nin daha güçlü olacağı düşünülmüştür. Osmanlı kimliği hem modernleşmeye karşı hem de modernleşmenin bütün araçlarını kullanmak gelişim sürecine modernleşmeyle paralellik gösteren bir toplumsal tepki olarak da gösterilebilir. Resmi olarak İslâmcılık Abdülaziz döneminde İttihad-ı İslâm şeklinde kullanılmaya başlanmıştır. Lakin daha güçlü bir şekilde İslâmcılık ideolojisi II. Abdülhamid döneminde ortaya çıkmıştır. II. Abdülhamid, iktidar sıfatını; sultan, padişah ya da hükümdar yerine halife konumunda olduğunu vurgulamak için halife olarak daha çok kullanmıştır.

\subsection{Avrupa Kimliği}

Geçmişten beri bütün toplumlar kendilerine bir yerde konumlandırmak bir kimliğe ait olmak için ve kendilerini diğerlerinden farklılaştırmak amacıyla kimlik arayışında olmuşlardır. Avrupa toplumlarında karşılaştıkları kendi dışındaki tehditler sonucunda bu arayışa yönelmiştir. Toplumlar kendi kimliklerini oluştururlarken, kimi zaman da kendilerini tehdit olarak algıladıkları ötekileri ortak kimliklerin olmasını istememişler, onların dillerini dolayısıyla zamanla da kültürlerini ayrıştırmaya çalışmışlardır. Türk dili ve toplumu da özellikle Kafkasya'da Ruslar tarafından bu farklılaştırmaya maruz bırakılmıştır. 1. Dünya Savaşı sonucunda Osmanlı Devleti'nin yenilip, galip tarafın Osmanlı Devleti topraklarını kendi aralarında paylaşıp, imparatorluğu parçalayacağı, imparatorluk içinde yer alan toplumların kendi kaderini tayin edeceği ilkesini destekleme tavrı olmuştur. Bu tutumdan sonra elbette Osmanlılar, kendilerinin de millet olma şeklinde kimliklere intiyaç duydular. Avrupa kimliği kavramsallaştırılması $A B$ projesinin siyasi ve ekonomik boyutunun cisimleşmesiyle birlikte sosyal boyutundaki gereksinimlerinin karşılanabilmesi adına bir takım ortak değerler etrafında organik Avrupa coğrafyası, dışındaki ötekiler üzerinden kendini tanımlayan bir olgu olarak ortaya çıkmaktadır (İnanç, 2005: 129).

Eski Yunan döneminde, Roma İmparatorluğunun başlangıcı dahil Avrupalılık fikri görülmektedir. Avrupa'yı tek çatı altında toplayan siyasal güç Roma İmparatorluğu'nun yıkılmasıyla Avrupa rekabet içine düşmüş ve uzun zaman birliktelik göstermemiştir. Avrupa'da çok eski tarihlerden itibaren ortak bir sosyal kimlik arayışı oluşmuştur. Önceleri coğrafi bir anlam olarak kullanılan Avrupa kelimesi Roma İmparatorluğunun perslerle savaşmaya başlamasıyla siyasal bir boyut kazanmaya başlamıştır. 7. yüzyıldan itibaren İslâmiyet'in yayılmaya başlamasıyla Avrupalııı kimliği 
oluşmuştur. Avrupa, Hristiyan kimlik altında bir bütünlük göstermiş gibi olsa da Orta Çağ'da toplumları çok küçük parçalara ayırmıştır. İtalya'dan Flander'e Macaristan ve Polonya sınırlarına kadar yüzlerce prenslik, düklük ve şehir devletleri kurulmuştur. Avrupa'nın 80 milyon nüfusu iki yüz kadar devletçilik ve benzeri yapılanmalar oluşmuştur. 14. yüzyılın sonu ve 15 . yüzyılın başında yerel ve milli devletler kurulmaya başlamış, papalık ve imparatorluk müessesesi sarsılmıştır. Milletleşmenin yayılmasıyla başlayan üstünlük çabaları ve ayrılık yaşayan Avrupa devletlerinde Osmanlı Devleti'nin 15. yüzyılda, batıya doğru hızla genişlemesiyle Avrupa ve Hristiyanlık kavramları yeniden güçlenmeye başlamıştır. İstanbul'un Türklerin eline geçmesi ile II. Pius Avrupalılar hitabıyla yaptığı çağrıya Hristiyan ordusu kurulmuş, II. Pius'ün vefatından sonra ordu dağılmış olsa da Hristiyanlar, Avrupalı kimliğin etkisini devam ettirmiştir. Anlaşılacağı üzerine Aslında "Batı Kimliği" doğudan gelen Osmanlı Devleti'nin tehdidine karşı bir seferberlik başlatılmasıyla oluşan, Avrupalıları kendini ötekilere karşı bir koruma içgüdüsüyle sahiplendiği bir kimlik olarak görülmektedir (Tekin, 2013: 541).

18. yüzyıl aydınlanma dönemiyle birlikte Avrupa, Hristiyanlık dini yerine medeniyet kavramıyla tanınmış ve medeniyet kavramıyla da anılmaya başlamıştır. Bu sayede dünyada medeniyet sahibi olan modern ve gelişmiş batıyla ilkel ve gelişmemiş ötekiler gibi ikili zıt bir yapılanma oluşmuştur. Kendisini yücelten ve kendinden olamayanı aşağılayan bir zihniyet sergiledikleri, açık bir şekilde anlaşılmaktadır. Bunun nedeni doğuya ya da batılı olmayan her kimlerse onlara karşı bir savunma oluşturabilmektir. Savunma için güç, gücünde tek yolu Avrupa olarak birlik bütünlük oluşturabilmelerinden geçiyordu. Ama bu çok zor gerçekleşecek bir arzuydu, çünkü Avrupalı devlet, kralık ya da hanedanlıklar tarih boyunca birbirlerinin kanlarını dökerek ayrışmış ve bundan kaynaklı birbirlerine tahammülsüzlükleri vardır. Ulus devlet süreçlerinden sonra ekonomiye ve modernleşme istekleri gayesinde birbirlerine karşı daha anlayışlı ve çıkar ilişkili birliktelikler kurdukları anlaşılabilir.

Müge Tekin'in Avrupalıların bu ayrışmalarının, birliktelik kurmaları husustaki güçlükleri daha iyi anlatabilmemiz için, şu tespitini vermememiz yararlı olacaktır.

"Fransız Devrimi'nden sonra tek bir Avrupa oluşturma çabası içerisine giren devlet adamı Napolyon Bonapart'tır. Napolyon Avrupa'da kazandığı zaferler sonucunda kıta sistemi kurmayı amaçlamıştır, ancak egemen gücün Fransızlarda olmasını istemesi, diğer toplumları rahatsız etmiş ve bu amacına ulaşmasına engel olmuştur. Fransız İhtilaliyle ortaya çıkan milliyetçilik 1914 yılında 1. 
Dünya Savaşı'nın başlamasında önemli rol oynamıştır" (Tekin, 2013: 541-542).

Anlaşılması gereken aslında Avrupa kimliği bir aidiyetten daha çok çıkar kenetlenmesi, özümsenmesi şeklinde ifade edilmelidir. Dünyayı sürükledikleri iki savaşta birbirlerinden hazzedemedikleri içindir.

\section{ARAŞTIRMANIN METODOLOJİSi}

\section{1. Çalışmanın Konusu}

Çalışmanın konusunu; Türk ulusal kimliğinin Türkiye Cumhuriyeti inşa sürecinde, 1839 Tanzimat Fermanıyla başlayıp, Cumhuriyetin ilanı 1923 ve Atatürk'ün vefatına kadar süren, ilke ve inkılapların kabulüne kadar geçen zaman diliminde içerdiği anlamlarının sosyo-politik bağlamlarıla ele alınması oluşturmaktadır. Osmanlı Devleti'nin de ve üzerine inşa edilen Türkiye Cumhuriyetin de ortaya çıkan ideolojiler, kimlik anlayışları, toplumsal değişim ve benimsetilen, benimsetilmeye çalışılan üst kimlik algısı, toplumda bu kimliklerin nasıl algılandıkları ve bu kimliklerin neler oldukları incelenmektedir. Batılılaşma girişimleri ve modernleşme çabaları çerçevesinde ulus devlet inşa sürecinde gerekli olan resmi kimlik şartını gerçekleştirilebilmesi için Osmanlı Devleti'nde Avrupa hegemonyasına karşı, savunma stratejileri ve ortaya çıkan üst kimlik, çabaları araştırılmıştır. Osmanlı Devleti'nde geleneksel ideolojilerin terk edilmesi ve Cumhuriyet öncesi başlayıp doğal bir süreç izleyen modernleşme girişimleri, Cumhuriyetin ilanı sonrası hangi amaçlar doğrultusunda yukardan inmeci, toplumun içine sinmeyen bir ikinci el elbise gibi giydirilmesi araştırılmaktadır. Devletin sağlam temeller üzerine kurulması neden kimlik inşasındaki ideolojik tutumlarla zedelendiği, tartışma konularımızın ana çerçevesini oluşturmaktadır.

\section{2. Çalışmanın Önemi ve Amacı}

Günümüze kadar geçen sürede gerek akademik camiada gerekse farklı mecralarda olsun, kimlik, kimlik inşası, Türk ulusal kimliği konuları üzerinde çalışmalar yapılmıştır. Bu çalışmaların çoğu Türk ulusal kimliği inşa sürecinde, Cumhuriyet Dönemi inşa sürecine kadar geçilen aşamalar, daha dar kapsamda tutulduğu ve devam eden kimlik inşası süreci sınırlı miktarda ele alındığına rastlanır.

Türk ulusal kimliğinin, gerçekten söylendiği gibi bir üst kimlik kurgusu günümüzde eleştiri bombardımanına tutulur, etnik kimlik yapısından kurtulamadığı söylenir. Bu doğrultuda 1924 'de söylenen bütün etnik milletleri kapsadığı gösterilen Türk milleti, neden günümüzde tartışılıyor. Bunun için dönemin karakteristik özelliklerini araştırılarak, ortaya 
çıkarılması önemlidir. Bu çalışmayla birlikte Tanzimat Fermanı'yla başlayan modernleşme girişimlerinin toplumda algılanması, kimlik anlayışında değişimler, cumhuriyetin kuruluşundan sonra devam eden modernleşme, toplumda değişim ve dönüşüm konusunu ele alması yönünden önem arz eder. Bu alanda daha fazla çalışmalar yapılmasıyla kendi kimliğimizi çok daha iyi anlayabilmemiz için gereklidir. Türk ulusal kimliği konusunu daha dar kapsamlı ele almış olsak da her bölümde işlenen üst kimlik algısı kendi içinde ayrı bir önem arz eder. Çalışmanın içerisinde geçen Türk ulusal kimliğinin, Avrupa kimliğine, İslâm kimliğine hatta topluma karşı konumu ele alınarak o dönemin amaçları, evrensel dünya düzeninde Türk ulusal kimliğinin yerini ve önemini anlaşılması, modernleşme, girişimlerinin hızını, yönünü nasıl ve kimler tarafından gerçekleştirildiğini anlamamız gereklidir. Günümüzde Türkiye'nin kimlik algısını, kimlik tartışmalarının temelini daha kapsamlı anlamamızı sağlaması için bu çalışma önemlidir. Ancak bu kadarla kalarak anlamamız elbette yeterli değildir. Türk ulusal kimliğinin kurumlar tarafından inşa edilmeye çalışılması da her bir kurum ele alınarak da incelenmelidir. Kurumlarla birlikte inşasına gayret edilen Türk ulusal kimliğinin yalnız cumhuriyetin inşa sürecinde kalmayıp Osmanlı Devleti'nin son iki yüz yıllı da incelenmesi gereklidir. Cumhuriyet sonrası Atatürk'ün 1923 'ten 1938'e kadar ve ondan sonraki tek partili yıllarda titizlikle incelenmesi gerekmektedir. Bu çalışma 1839'dan 1923'e kadar toplumsal kimlik algısının değişim dönüşümünü sadece 1923'ten sonrasını değil Osmanlı Devleti'nin son dönemlerindeki modernleşme, batılılaşma, toplumsal kimlik algısının üst kimlik kabullerini ortaya çıkarılması amacıyla böyle bir çalışma intiyaç duyulmuştur. Çalışmada Osmanlı Devleti'nin son dönemlerinde ortaya çıkan ideolojilerin tek tek ele alınarak Türkiye Cumhuriyeti'nin ilanıyla beraber fikir ayrışmaları, değişen kimlik, devlet eliyle ortaya konan Türk ulusal kimliği, çeşitli kaynaklardan faydalanarak ele alınmış, Türk ulusal kimliğinin toplum ve dünya üzerindeki yeri ve öneminin, amacının ne olduğu ortaya konulmasına çalışılmıştır. Osmanlı Devleti'nden, Cumhuriyete miras kalan etnik zenginliklerimiz kendilerini Türk milleti içerisinde 1924 Anayasasında vaat edildiği gibi yer bulmuş mudur? Türk ulusal kimliği, Türk etnik özellikleri mi sergilemektedir yoksa cumhuriyetin kurulmasına katkı yapan bütün milletlerin sentezini mi sergilemektedir? Neden ulusal kimlik olarak Türk kimliği seçilmiştir? Günümüzdeki tartışılan soruların cevaplanabilmesi için kavramın ilk ortaya çıktığı döneme gidilmeli ve toplumsal, siyasi koşullar göz önünde bulundurularak incelenmelidir. İnsanların hislerine, kendilerini konumlandırdıkları yeri, çevresini ve zihniyetini sahip oldukları kimlikler çerçevesinde belirlerler. Bu yüzden kimlik, bir insanı nasıl etkiliyorsa, bir ulusu bir imparatorluğu ne ölçüde etkilediğinin de araştırılması önemlidir. 


\section{3. Çalışmanın Yöntemi ve Sınırlaması}

Çalışmamızda, kimlik dönüşümü konusu, 1839'den 1938'e kadar geçen dönem incelenerek, konu iki tarih arasında sınırlandırımıştır. Tarihi bir dönemi çalıştığımız ve dönemin karakteristik özellikleri bağlamında konuya yaklaştığımız için "Dokümantasyon Metodu" kullanılmıştır. O tarihteki belgeler üzerinde inceleme yaparak, yapılan incelemeler, analiz edilerek, araştırmak istediğimiz konu için bilgiler elde edebiliriz. Olmuş ve bitmiş olayları, ideolojileri öğrenebilmemiz için arşiv, dönem gazetesi, yazılı metinler, edebi eserler, sosyolog için en büyük kaynaklardandır. Bilim olmuş ve olmakta olan olaylardan olmuş olanları belge tarama metodunu kullanır. Bizim çalışmamızda tarihi bir dönemi anlamaya yönelik olduğu için belge taraması gerçekleştirilmiştir (Arslantürk ve Amman, 2013: 45).

Kimlik, kimlik inşası, üst kimlik, milli kimlik ve Türk ulusal kimliği, Cumhuriyet dönemi tarihi, milliyetçilik, Türk milliyetçiliği, Osmanlı Devleti'nin son dönemindeki ideolojik akımlar ve araştırmanın içeriğine girebilecek konuların ele alındığı makaleler, ansiklopediler ve kitaplar gerek satın alınarak gerekse kütüphanelerden teslim alınarak elde edilmiştir. Sakarya Üniversitesi Merkez Kütüphanesinin sunduğu veri imkanları önemli olmak üzere araştırma için çeşitli kaynaklara başvurulmuş, kitapların önemli bir kısmına üniversite kütüphanesi sayesinde ulaşıımış, makalelerin önemli bir kısmı da internet üzerinden ulaşılarak incelenmiştir. Üst kimlik anlayışı, kimlik inşası ve dönüşümü, Cumhuriyetin ilanı 1923 ve temel kurumlarının değişip dönüştüren, ilke ve inkılapları içerisine alacak şekilde, 1839 Tanzimat Fermanından başlayarak Cumhuriyetin ilanı ve daha sonrası 1938 Atatürk'ün vefatına kadar süre içerisinde sınırlandırılmıştır. Atatürk'ün ölümünden sonra Batılılaşma girişimleri, yenilikler, politikalar çalışmaya dâhil edilmemiştir.

\section{4. Çalışmanın Varsayımı}

Türkiye Cumhuriyeti inşa sürecinde, Osmanlı Devleti'nin 19. yüzyılda başlayan Avrupa'daki reform hareketlerinin, milliyetçilik ideolojilerinin, Osmanlı'ya yansımasının toplum üzerindeki belli grupların ayrışması bu ayrışmayı önleme girişimlerinin yeterliliği ne denli başarılı olduğu modernleşme girişimleri toplumsal hareketliliğin devlet yapısının değiştirildiği bu yapılanmalardaki, devlet kurumlarında örgütlenmelerin başarı nispetinde gerçekleşmiştir. Bu kimlik değişiminde yanı üst kimlik oluşturma çabalarında, Osmanlı aydınları, devlet yöneticileri, Avrupa'daki reform hareketleri, Osmanlı Devleti'ndeki azınlıklar ve Kurtuluş Savaşı'ndaki devlet idaresi ve yönetim kadrolarının etkileri doğrudan bulunmaktadır. 


\section{5. Çalışmanın İçeriği}

Çalışmanın temel ekseni anlaşılması için kimlik, kimlik inşası, milli kimlik, Avrupa kimliği ve İslâm kimliği kavramlarının açıklanması önem arz etmektedir. Üst kimlik olarak Türk kimlik algısı incelenen dönemlerin kapsamlı bir şekilde ele alınması ve yapılan girişimlerin neticeleri tespit edilerek, dönüşüm anlaşılmaya çalışılmıştır. Ulusal kimlik inşa sürecinde egemen iktidar tarafından ortaya konulan icraatlar ele alınmıştır. Bu genel teorik çerçeve üzerine Türk milletinin özellikleri Atatürk modernleşme hareketleri, ideolojik akımlar açıklanarak, Türk ulusal kimliği genel hatlarıyla ortaya konmaya çalışılmıştır. Türk kimliğinin üst kimlik olması yönündeki girişimlerinin geçirdiği evreler Osmanlı Devleti'nin son dönemindeki akımların yapısal farklılıkları yani devletin kurucularının benimsedikleri ideoloji genel hatları ile ifade edilmiştir.

Türk kimliğinin karşısında yer alan ideolojiler, kurumların bu süreçte değişmesi bazı kurumlar üzerinden konu edilmiştir. Bu çerçevede eğitim kurumu, yeni politikalar Cumhuriyet öncesi ve sonrasındaki değişimlere yer verilmiştir. Araştırmanın ana çerçevesini oluşturan üç bölümde ilk önce 1839 'da Gülhane Parkı'nda okunan Tanzimat Fermanı ile başlanarak 1923 ve Atatürk'ün vefatı 1938 yılına kadarki süreçte dönemin genel özellikleri detaylı bir şekilde ele alınmış olup Osmanlı Devleti'nin son dönemi ile başlayan modernleşme, batılılaşma hareketlerinin nedenleri konu edilmiştir. Dönemin karakteristik özellikleri açıklanırken Türkiye Cumhuriyet'in kuruluş döneminde yeniden inşa edilen üst kimliğin nasıl bir temel üzerinden yükseldiğini açıklanmaya çalışılmıştır.

\section{Cumhuriyet'in İnşa Sürecinde Türk Kimliği}

\subsection{Dönemin Karakteristiği ve Tarihsel Gelişimi}

Avrupa' da reform hareketleri, teknolojideki gelişmeler, balkanlarda milliyetçilik ayrışmaları, Osmanlı Devleti'nin çöküş dönemi, 1. Dünya Savaşı, savaş sonrası toplumun topyekûn Kurtuluş mücadelesine girmesi gibi sosyolojik, siyasi, iktisadı alanlarda gelişmeler, değişimler kimlik üzerindeki algıları, ideolojileri de beraberinde değiştirmiş, ayrışmalara ya da birlikteliği neden olmuştur. Osmanlı Devleti'ndeki kimlik anlayışı ile Cumhuriyet ideolojisindeki kimlik anlayışı farklılaşmış, dayanak noktalarındaki farklılıklarda, hakım olan ideolojiye göre şekillenmiştir. Cumhuriyet döneminde, daha rasyonel bir bağ vurgusu yapılırken, Osmanlı Devleti'ndeki, kimlik ve toplum arasında kurulan bağın dini temellerinden dolayı gerçekçiliğe uzak olduğu vurgusu yapılmıştır.

Kimlik algısı üzerindeki etkenlerden en önemlilerinden bir tanesi olan Avrupa'da meydana gelen toplumsal hareketliliklerdir. Avrupa'nın 
topraklarında 18. yüzyılda gerçekleşen aydınlanma ve 19. yüzyılda gerçekleşen sanayileşmeyle Avrupa, dünyanın geri kalan toplumlardan daha güçlü konuma gelmiştir. Bu elde edilen güçle birlikte kendisini diğerlerinden farklı konumda görmesiyle diğer toplumları ötekileştirmiştir. Bu ötekileşme diğerlerini aşağılayan bir bakış açısını barındııı. Kendilerini diğerleriyle aynı görmek onlar için rahatsızlık yaratmıştır. Kendisini merkeze koyarak karşılaştırmalar yapmış ve farklı olanlar ötekileştirilmiştir. Bu nedenle öteki kültürlerin varlığını kabul etmede önemli zorluk yaşamıştır. Batıda meydana gelen bu denli tek tipleştiren kimlik anlayışı beraberinde kopuşları, kargaşayı ve toplumsal ayrışmalara neden olmuştur. Avrupa'nın dünyanın diğer toplumlarını, kültürel özelliklerini ötekileştirmesi, Avrupa'nın kendilerini beğenmişliğinden başka bir şey değildir. Güçlü gözüküp, dünyanın en modern, en çağdaş toplumu ve ırkı olarak kendilerini en üst yerlere konumlandıracaklarını sanarak, örnek alınacak diğerleri tarafından hayranlıkla izlenecek bir medeniyet olacaklarını zannetmelerinden başka bir şey de değildir (Altun, 2013: 54-55). Biz kendi tarafımıza dönersek, Avrupalıların kendilerini etnisiteye hatta biyolojik özelliklerine göre üstte, asil görmesi ötekileştirilen diğer toplumlarında sınıflandırmaların ne kadar yanlış olduğu belirtilmelidir. Kendi milletimizin, toplumumuzun temelleri en iyi şekilde aydınlatılmalı, dayanak noktalarımız iyi bir şekilde gün yüzüne çıkarılmalıdır. Bu sayede Avrupa hegemonyasını yıkabilir, en ağır eleştirileri söyleyebiliriz. Türk milleti kavramının tarihçesine Osmanlı Devleti'ne değinerek açıklamalara başlamak doğru olacaktır. Türk milleti kavramı Osmanlı Devleti'nde 18. yüzyılın ikinci yarısında duyulmaya başlandı, 18. yüzyılın sonlarına doğru batıda ortaya çıkan milliyetçilik ideolojisi toprakla insanlar arasında ilişki kuruyordu. Milliyetçilik ideolojisinden etkilenen Osmanlı vatandaşları da vardır, nasıl Rusya'da Ruslar, Almanya'da, Almanlar, İspanya'da İspanyollar varsa, Türkiye'de elbette Türkler vardır çıkarımı yapılmıştır. Türklerin milliyetçilik doktrinden etkilenmesi doğaldır. Bu yüce, bereketli topraklar yüz yıllar boyunca milletimize, yer yurt olmuştur. Türk milliyetçiliğiyle Türk adı hem kutsallaştırılmış hem de kimlik algısının temeli olarak sahip çıkılmıştır. Osmanlı Devleti'nin yerine kurulan Cumhuriyet Türkiye'si de bu ideolojik bakış açısıyla devlet adında Türk kelimesi yer almıştır (Güvenç, 2008: 23). Osmanlı Devleti'yle elde ettiğimiz güç hem dini hem de siyası otoritesiyle birlikte dünya üzerinde, özellikle bölgesel bir etkiye sahip olmuştur. Avrupa'da ortaya çıkan toplumsal hareketlerin, toplumları ayrıştırma, ötekileştirme girişimlerine yukarıda değinilmiştir. Bu ötekileştirme kimlik üzerinde toplumları bir bunalıma ayrışmaya, çatışmaya neden olacağı kaçınılmazdır. Bir diğer ifadeyle kişi, grup ve toplulukların resmi bir şekilde kimlik üretimi başlı başına bir sorun alanını da ortaya çıkartmaktadır. Buradaki sorun insanları farklı kimliklerle 
ayrıldığı zaman değil de tek bir kimlik altında birleştirilmeye çalışıldığında kendini göstermektedir. Çünkü bu kimliklendirmeyle birlikte bireysel kimlikten ziyade ortak ulusal bir kimlik benimsetilmeye çalışılmaktadır. Üyesi olunan toplum ya da vatandaşı olunan devlet artık bireylerden yalnızca yasalara uymasını, ülke çıkarlarına hizmet etmesini değil ülkenin resmi tarihine, ülküsüne, ritüellerine inanmasına yani resmi kimliği adeta bir giysi gibi tartışmadan gururla üzerinde taşımasını da beklemektedir. İnsan üzerine görev yükümlülük yükleyen kimlik algıları, bir kısıtlama, yaşam alanını daraltması, ulus devlet anlayışına yönelik eleştirilere neden olmaktadır. Avrupa devletlerinde gözlemlenen bu anlayış, Cumhuriyet Türkiye'sinin kuruluş, inşa sürecinde de gözlemlenmektedir. Ulus devlet anlayışı gücünü haltan alması gerekir. Halk sayesinde meşrulaşabilir ve toplum adına karar verme yetkisine erişebilir. Ulus devletler zorunlu olarak kendi milletlerini tanımlaması gerekir. Meşruiyetinin kaynağını ortaya koyduğu milletiyle açıklayabilir. Bu kolay değildir, çünkü ulus devletin istediği resmi kimlik, birçok bireysel kimliği görmezden gelir. Bu görmezden gelme ulus devletlerin başlıca meşru işlevlerinden ve unsurlarından olduğu zannedilir. Ulus devletin dışında resmi kimliği içselleştiremeyen etnik kimlikler, milli birliğin karşıtı olarak suçlanabilirler. Bu suçlamaların kaynağı elbette farklıııkların ortadan kaldırılarak toplumu aynı aidiyet bağına sahip homojen gösterilme çabalarından da kaynaklamaktadır (Güvenç, 1993: 68).

Balkanlarda ortaya çıkan milliyetçilik hareketleri, toplumu oluşturan faklı milletlerin ayrışmasına, ideolojik çatışmalar neden olmuştur. Fransız devrimi milliyetçilik üzerinde etkili olan bir başka husustur. Daha sonra farklı milletlerin milliyetçilik algısından etkilenilmeler olmuştur. Türk milliyetçiliği Fransız devriminden etkilenerek maddi ögelerden ziyade soyut moral ve manevi ögeleri ön plana tutan bir ideoloji benimsemiştir. Daha sonra Alman ve İtalyan etnik milliyetçiliğimden de etkilenilmiştir. Türk milliyetçiliği hem Fransız hem de Alman ve İtalyan milliyetçiliğinin karışımından oluşmuştur. İki farlı görüş Türk milliyetçiliği şekillenmiştir. Bu neticeler sonucunda, kurulan Cumhuriyet Türkiye'sinde Türkçülük ideolojisi güçlendirilmiştir, zaten Osmanlı Devleti'nden sonra kurulan yeni devletin temelini bütün farklı etnik kimlikler kapsayan, bir üst kimlik inşası için çabalamıştır. Türkçülük'le hiçbir etnik kimlik farklı görülmeden kolektif zihniyet bilincine sahip bir toplum inşası düşünülmektedir. Geçmiş zamandan beri süregelen kimliğin vurgusu yapılmıştır. Cumhuriyet dönemi düşünürlerinden Ziya Gökalp'te Türklüğü önemli görmekte ve kimlik olarak Türkçülüğü tanımlarken, kapsayıcı siyasal iradeci tarihsel ve kültürel alanda organik dayanışmacı bir millet şeklinde ifade etmiştir (Alakel, 2011: 23). 
Birleştirici kimlik olarak kurgulanan Türk ulusal kimliği bir üst kimlik olarak kabul görülmesi istenmiştir. Türkçülük, Türk milliyetçiliği ifadeleriyle oluşturulmaya çalışılan üst kimliğin, siyasal, kültürel alandaki etkileri, temellerinin ve kapsamının açıklamaların bir kısmı yukarıda belirtildiği gibidir. Bir ulusun üst kimlik algısı, ulusun varlığını koruya bilmesi için önemli olup, tarihsel süreci ve etki alanları iyi bir şekilde incelenmelidir. Bir ulusun resmi kimliği o ulusun tamamını şekillendirmede ve yaptırım gücüne sahip olmada etkindir. Bundan dolayı resmi kimliklerin kapsayıcılıkları ve tarihsel, sosyolojik, kültürel gerçeklikleri büyük önem taşımaktadır. Nitekim daha önce de belirtildiği gibi tanımlanacak heterojen grubun ortak paydalarından ve benzerliklerinden hareketle yapılacak bir kimliklendirme o kimliğin kabul edilebilirliğini de arttıracaktır.

Avrupa'da ortaya çıkan ulusçuluğun resmi kimlik üzerindeki etkisini bununda Osmanlı Devleti'nin yerine kurulan modernleşmeyle değişen ideolojilerin Türkiye'deki kimlik algılarına etkisini anlayabiliriz. Türkiye'de kimlik algısında değişim daha önce de belirttiğim gibi modernleşme, Cumhuriyet ilanından sonra gerçekleşmiş bir durum elbette değildir. Kimlik dönüşümü Türkiye'de hız kazandığı zaman olarak gösterirsek Osmanlı Devleti'nin sonu, cumhuriyetin ilk yılları, doğru olacaktır, bu zaman diliminin önemi anlaşılmalı ve titizlik ile incelenmesi gereklidir. Balkanlarda yaşanan milliyetçilik ayrışmaları, ortaya çıkan milliyetçilik görüşleri, kimlik dönüşümü üzerinde en büyük etkiye sahip bir görüştür. Bu bağlamda Türkiye'de milli kimlik hususunda yaşanan dönüşüm incelenecek olursa 19. yüzyılın son çeyreğinde modernleşme ve milliyetçilik eksenli yaşanan ideolojik dönüşüm yol gösterici olabilir. Milli kimliğin şekillenmesinde etkili olduğu söylenebilecek olan bu ideolojik dönüşümün anlaşılabilmesi için ise kısa bir arka plan sonrasında bu akımların incelenmesi yerinde olacaktır. Osmanlı Devleti birçok milletten oluştuğu içim imparatorluk denilmektedir, milliyetçilik ise birçok etnik grubu birlikte bir arada yaşaması için engel nitelik taşımaktadır. Milliyetçilik ideolojisi gücünü aldığı unsurlar arasında kan bağı, gibi farklılıkları ötekileştiren bir görüş mevcuttur. Osmanlı Devleti'nde dil, din, mezhep, kültür gibi farklılıkların bir arada yaşadığı tek bir bağın olmadığı unsurlar mevcuttu ve milliyetçilik tamamen tehdit gözükmesi doğaldır. Osmanlı Devleti için bu ideoloji yıkıcı gözükmekte, dolayısıyla Osmanlı Devleti'nin milliyetçilikle arasına bir mesafe koymasına neden olmaktadır. Fakat başlangıçta Osmanlı Devleti'nde, devlet adamları ve toplumu için yıkıcı gözüken bu ideoloji, sonrasında imparatorluğu bir arada tutmanın aracı veya yöntemi olarak görülmeye başlamıştır. Bir diğer ifade ile milliyetçiliğin İmparatorluk'ta, son derece yıkıcı etkileri olabileceği açıktır. Bu etkilerden korunma ya da zararı minimize etmenin ise önemli bir 
husus olduğundan bahsedilebilir. Bu noktada bir anlamda milliyetçiliğe karşı, milliyetçiliğin bir araç olarak kullanılması söz konusudur. Ancak bu şekilde milliyetçiliğin zararlarından en küçük kayıplarla kurtulabileceği düşünülmüştür. Şimdi de çözüm olarak kaçınılmaz bir şekilde kabul görülen Türk milliyetçiliği açacak olursak, anlatılmak istenilen sorunlar daha iyi anlaşılacaktır (Mardin, 1995: 94).

İttihad ve Terakki'nin Türk milliyetçiliği oluşumunda elbette en büyük payı Türk Ocakları Kurucu heyeti olmasıdır, heyet içerisinde Ziya Gökalp'in dan sonra Yusuf Akçura gibi önemli düşünürler mevcuttur. Bu Türk Ocaklarının hedefi, milliyetçiliğinin kaygıları yok ederek, ulusal kimliğin yeniden keşfini sağlamak, Batı merkezli değerler ve kurumları karşısında aydınlar içerisinde yaygınlaşan aşağılık kompleksini aşarak, İslâm'la politika arasındaki ilişkiyi yeniden tanımlamaktır. Atılan adımlar ortaya çıkarılan büyük söylemler bu amaçla yapılmıştır. Ortaya çıkarılan, adeta bir reçete olarak düşünülen devlet ve yönetici elitler eliyle şekillendirilen birleştirici tarzdaki bu milliyetçilik, o ana kadar görülmeyen bir ihtiyaç olarak devletin kendi milletini tanımlaması gerekliliğini yani kimliklendirme politikalarınıda ortaya çıkaran bir gelişme olmuştur.

Milliyetçiliğin bu denli etkili bir benlik yansıtmasının olumlu ve olumsuz yönlerini açıklayarak ilerlemek, kimlik dönüşümü konusunu anlamamız için önemlidir. 19. yüzyılın ortalarında Avrupa devletlerine göre gecikmiş bir şekilde başlayan milliyetçilik, 20. yüzyılın ilk çeyreğine kadar ki döneme ve şartlara bağlı olarak bir değişim ve gelişim çizgisi izlemiştir. Milliyetçilikte yaşanan bu değişim kuşkusuz ki kimlik politikalarını da çok yakından etkilemiş ve onda da çeşitli değişiklikler görülmesine neden olmuştur.

Kimlik algısındaki değişim sonucunda Osmanlı Devleti'nin Osmanlıcılık kimliğinin ardından İslâmcılık, Batıcılık ve Türkçülük gibi yeni siyasal akımlar sahneye çıkarak, her bir ideolojiyle yeni kimlik inşaları yaşanmıştır. Ortaya çıkan kimlik görüşleri birbiri ardına çıkmasının nedeni ise bir önceki ideolojinin toplumu bütünleştiren üst kimlik olmayı başaramadıklarındandır. Bu dönemde devlet yöneticileri ile aydınlar kimlik inşası için önemli aktörler olarak görülür. Devlet yöneticileri kendi taraf olduğu ideoloji ile aydınların ideolojisi de toplum üzerinde etkili olamaması iyi bir şekilde araştırılıp cevap aranması gereken bir başka konudur. Devlet yöneticilerinin kimlik inşası ya da bu inşa sürecine engelleri kaldırma yönelik yaptırım uygulamaları vardır. Cumhuriyet ilanından sonra devlet yöneticilerin benimsedikleri ideoloji ve bu doğrultuda aldıkları, önlemler ve yenilikler halkın içinde geleneksel ideoloji taraftarlarını bastırmaya, sindiremeye yöneliktir (Karakaş, 2013). 
Tanzimat Fermanı'yla başlayan, Cumhuriyetin ilanına kadar olan sürede, Avrupa'da ortaya çıkan milliyetçilik rüzgârı Osmanlı Devleti'ne etkileri, devletin kendini müdafaa edebilmek için ortaya çıkan fikir ayrılıklarıyla ele alınması gereken kimlik dönüşümlerinin o döneme ait özelliklerine değinerek alt olayları kısaca açıklamak sonrasını anlamada yardımcı olacaktır. Şimdi üst kimlik, resmi kimlik olarak inşa edilmek istenilen Türk kimliğinin önündeki engelleri, etkileri ele alarak konuyu temel hatlarıla bir neticeye varabilelim.

\subsection{Avrupa Kimliği Karşısında Türk Kimliği}

Osmanlı Devleti, birçok etnik grubun yüzyıllar boyunca bir arada yaşadığı, hoşgörü sahibi bir imparatorluktur. İmparatorluğun son yıllarında, ortaya çıkan etnik ayrışmayla başlayan çözülme, imparatorluğun yıkılmasına ve kurtuluş mücadelesiyle başlayan mücadele süreciyle beraber yeni bir ulusal devlet kurma süreci ve bu devletin ulusal bir kimlikle güçlendirilmesi gerekli oluşmuştur. Bu doğrultuda ulusal kimlik, sivil anlayış çerçevesinde araçsal bir yoldan inşa edildiği ortaya çıkıyor. Buna göre sivil milliyetçilik teorisyenleri devleti ulusal kimlik oluşum sürecinin başlangıç noktası sayar. Orta Asya'nın bu toplumun kökeninde değil, son siyasi idari özelliklerini kültüründe ve değerlerini içeren Türk vardır. Lakin Osmanlı'da ve Türkiye Cumhuriyeti'nde var olan ırk bakımından Türk olmayan ama aynı kültürü ideayı ve dili paylaşan farklı etnik aidiyeti sahip milyonlarca Türk kimliğine sahip vatandaş mevcuttur.

Türk milleti sadece Anadolu'da yaşayan milleti değil 19. ve 20. yüzyıllarında Anadolu dışından aynı kültür ve değerlerin parçası olarak Anadolu'ya göç eden, ayrı dilleri konuşan milyonlarca insanı ifade eder. Türk kimliğinin tarihsel temeli, vatan olarak yüzyıllar boyunca yaşadığımız Anadolu'daki önemimizi bilmemiz gereklidir. Batı kimliğinin kendini diğer kimliklerden farklı görerek kendini konumlandırır. Avrupa kimliği, tarihsel geçmişten aldığı saf ırk teorilerine dayanan görüşlere nispeten, Türk kimliği de Avrupa kimliği karşısında aşağı bir kimlik olamayacağı, iki kimliğin de tarihsel süreç içerisinde önemli bir yere sahip olmakla beraber, Türk kimliğinin daha kapsamlı ve elde tutulan delillerle tarih sahnesinde ulaşıla bilir kanıtlara sahiptir. Avrupa kimliğindeki kırılmalarla ortaya çıkan sosyal hareketler neticesinde meydana gelen kimlik bunalımları, Osmanlı Devleti'ni de etkilediği ve ideolojik düşüncelerle bu yıkıcı rüzgârın karşısında durma çabalarını daha önce detaylı bir şekilde değinmiştik, konu kapsamında tekrardan değinerek ilerlemekte fayda vardır (Alakel, 2011: 13).

Türk kavramı sadece tarihsel süreç içerisinde Türklerin dillendirdiği ya da Orta Asya dan göç eden kavimlerin söylediği bir kavram değildir. Anadolu 
da yaşayan Osmanlı Devleti'nin toprak sınırları içerisinde yaşayan her dilsel, dinsel, etniksel farklııılara mensup unsurlar, Osmanlı Devleti dışında Türk olarak nitelendirilir (Güvenç, 2008: 15). Örneğin,

"Türkçe konuşan Anadolu halkına Türkiye adı Haçlı Seferleri sırasında Batılılarca verilmişti, Osmanlı milleti ve vatandaşlığı da Türk ve Türkiya gibi, Avrupa ve Batı icadı deyimlerdi. 19. yüzyıl onlarına kadar Türkler kendilerini Müslüman milletin üyesi olarak görüp algıladılar" (Güvenç, 2008: 22).

Batı Anadolu topraklarında yaşayan Müslümanları, kendi içerisinde ayırmayarak, Müslümanlar olarak nitelendirmek yerine Türk olarak nitelendirmiştir. Bu doğrultuda Türk kimliğinin Batı kaynakları tarafından da bir üst kimlik olarak algılanması, kapsayıcı ve bütünleyici sayıldığı düşünülebilir. Bu tarafta Türkler kendilerini İslâm'ın bir taşıyıcısı mensubu olarak görmüşlerdir. İslâm dininin şartları içerisinde hiçbir farklııı görmeksizin ayrım yapılamayacağı, herkesin eşit ve etnik bağlamda denk olduğu görüşü mevcuttur. Bu bağlamda Osmanlı Devleti'nde Türkçülük ideolojisinden önce İslâmcılık kimliği vurgulanmış, elbette 19. yüzyılın sonralarında bu kimliğin o zaman da üst kimlik olmayı başaramadığını sonraki bölümde daha kapsamlı göreceğiz. Türk kimliğinin Avrupa kimliği karşısında kendini konumlandırması bakımından incelersek tekrar Batı kimliğinin kendisini diğer kimliklerden üstün görmesini neticesi olarak bu denli önemli gösterilmeye çalışıldığı anlaşılır.

Türk kimliği eski zamanlarda olduğu gibi kendisinin güçlü hâkim bir kimlik olduğunu kanıtlama gayesi taşıdığı gözlemlenmektedir. Osmanlı Devleti'nde eski zamanlardaki güçlü günlerine geri dönme isteği elbette doğal karşılanmalıdır. Batı kimliğini, Osmanlı'nın altın çağını yaşadığı dönemde kendisinden daha geride olduğu bilinmekte Osmanlı'nın son dönemlerinde Avrupa'da meydana gelen Reform, Rönesans gibi toplumsal hareketlerle beraber geliştikleri, teknoloji alanındaki ilerlemeleri, Osmanlı'dan daha güçlü bir konuma onları yerleştirmiştir. Osmanlı Devleti'nde ve Cumhuriyet döneminde tekrar altın çağ zamanına yeniden batıdan ileri düzeye dönülebilmek düşünülmüştür. Elbette Batı elinde bulundurduğu bu teknolojik güçle kendini üst seviyede görebilir. Türk kimliği de tekrar gücünü toparlayarak Batı kimliğinin önüne geçmeyi başarabilir. Yukarıda değindiğimiz gibi Avrupa'ya karşı aslında bir hayranlıktan söz edemeyiz. Çünkü tarihsel süreçte batıdan ileri olduğumuz daha sonraki dönemlerde yapılan hatalarla bu gücümüzü kaybettiğimiz ve geriye düştüğümüz düşünülmektedir. Batının yaptığı gibi bizde hatalarımızdan dönüp yeniden altın çağımıza dönebilme hayallerine sahiptik. Cumhuriyetin ilk yıllarında yapılan inkılaplar tekrardan toplumu bir 
bütün halinde değiştirerek geri kalmışlığı düzelte bilecek olması düşüncesiyle atılmış adımlar olarak gösterilmiştir. Bu idealin merkezinde Türk kimliği önemli bir yere sahiptir, çünkü Türk kimliğinin tarihsel geçmişi diğer kimliklerin çok daha öncesine dayanmaktadır. Özümüzden güç alarak tekrardan Batı kimliği karşısında eski gösterişli ve güçlü günlere geri dönülecek inancına sahiptirler. Bu doğrultuda kimlik algısında değişim dönüşümler gerçekleştirilmiş Batı medeniyetinden yararlanılarak sadece araçsal olarak kullanılacağı düşünülmüştür.

Türk kimliğini üst kimlik olarak görüşleri ifade ederek bu tartışmalar üzerinde neden uzlaşım olamadığına değinecek olursak Şener Aktürk'ün ifadeleriyle şu şekilde anlatılır.

"Türk kimliğinin bir tarihsel süreci göz önünde bulundurulursa, Türkiye vatandaşlarının kendini Gürcü kökenli, Türk Arap kökenli, Türk Çerkez kökenli, Türk veya Kürt kökenli Türk olarak ifade etmeleri mümkün olmalı ama zorunlu olmamalıdır" (Aktürk, 2013: 278).

Cumhuriyetin ilanıyla bir adım daha ileri gidilerek azınlıkları, içselleştirebilecekleri bir kimlik olarak Türk kimliği ileri sürülmüş, kimlik koşulları esnekleştirilmiştir. Hedefte ilk önce dinsel ayrımcılıkların kaldırılması ve ulus devlet inşası için Osmanlıdan kalan milletleri çatısı altına alabilmektir.

"Üst kimliğin kapsayıcılığı en dışlanmış, gayrimüslimler üzerinden ölçülebilir. Elbette Rum, Musevi ve Ermeni kökenliler kendilerini çoğulcu bir Türk kimliğinin mütemmim yüzü olarak görmektedir. Bu konuya, Fener Rum Patriği Bartholomeos, Türk devletine, vatandaşlık bağıyla bağlı olan herkes din, mezhep, ırk ayrılmaksızın Türk'tür ifadesidir" (Aktürk, 2013: 279).

Türk kimliğinin, üst kimlik olabilmesi için bu önemli bir görüş sergilemektedir. Çünkü farklı etniklere mensup toplulukların liderleri tarafından Türk kimliğinin yeni kurulmuş Cumhuriyet Türkiye'sinde vatandaşlık bağına indirgenmiş olması Cumhuriyet sonrası benimsenen ideolojinin temeli niteliğini taşımaktadır. Osmanlı Devleti'nde Müslüman etnik gruplar arasında fark gözetmeksizin yasalarda bir sorumluluk yüklenmiştir. Lakin Müslüman olmayan gruplar bu sorumluluk kapsamında tutulmamıştır. Örneğin, askerlik vazifesi gibi vatanı görevlerden muaf tutulmuştur. Osmanlı Devleti'nin yerine kurulan Türkiye Cumhuriyeti bu ayrıcalıkları ortadan kaldırmaya çalışmıştır elbette tamamen bütün etnik grupları tamamen kapsayamamıştır.

Bu bağlamda Osmanlı Devleti'nden farklı bir devlet yönetim anlayışı benimsenmiştir. Bu anlayış tamamen demokratik son sözün millete dayalı 
olduğu bir yönetim biçimi olacak şekilde yapılandırılmıştır. Bu konuda devletin ilk önce kendi üzerine yüklediği sorumluluk halkın dönüştürülmesiydi, bu doğrultuda kararlar alındı ve halkın bu kararları kabulü sağlaması amacıyla politikalar gerçekleşmiştir. 1923, Cumhuriyetin ilanından sonra, devletin kurucu isimleri ve Atatürk liderliğinde yeni kurulan devleti modernleştirme ve batı ülkelerinin standartlarına getirmek için politik toplumsal ve kültürel alanda birçok köklü reformlar gerçekleştirilmiştir. Kurumlar etkili bir araç vazifesi üslenmiştir.

Birçok alanda yapılan bu yenilikler elbette en başlarında ve en önemlisi kuşkusuz laikliğin devlet yapısında benimsetilerek, dini sadece devlet işlerinde değil, toplumsal ve kültürel hayatında da dışarıda bırakılmasıdır. Yapılan inkılaplarda, Şapka kanunu, kılık kıyafet anlayışında, Medeni kanunun kabulü, hukuk anlayışında, Batı tarzının daha iyi benimsenmesi için ise Latin alfabesinin kabulü gibi yenilikler, değişimler ve buna benzeyen diğer reformlar beraber Türk toplumunu her alanda topyekûn değiştirmesi amaçlanmıştır.

Cumhuriyetin inşası sürecinde köklü toplumsal değişim ve dönüşüm yaşayan başka toplumlarda olabildiği gibi, Türkiye'de de ulusal devlet kurma sürecinde yeni toplumu yaratmak ve yaratılan yeni toplumun gereksinimlerine ve değerlerine uygun yeni toplum inşa edilmek için kurumlara özellikle de eğitim kurumuna merkezi rol biçilmiştir. Eğitim Kurumu'nun değiştirilmesi ve yeni eğitim sistemi ile amaçlanan devlet politikasının yeni topluma uygun rejimi güçlendirecek insan yetiştirmesi ve ekonominin ihtiyaç duyduğu nitelikli insan gücü yetiştirilmesi beklenmektedir (Eskicumalı, 2003'ten akt. Güllüpınar, 2012: 91).

$\mathrm{Bu}$ konu üzerinde tartışmalar çeşitlilik göstermektedir. Eğitim kurumunun önemini anlamamız için kimlik inşası konusu içerisine dahil etmiş olup, devlet eliyle bizzat uzun vadeli ideoloji benimsetme konusunda kurumların önemini nitelendirmeye çalıştım. Eğitim kurumunun önemi sadece kimlik inşasında Cumhuriyet Türkiye'si bağlamında ele almamalıyız. İttihad ve Terakki'nin ana ideoloji olarak benimsediği açık Türkçülüğün temel aracı da eğitimdir. Özel okullarda, Osmanlıcılık Türkçülüğe aykırı tüm tema ve unsurlar ayıklanacak ve Maarif Vekaleti nezaretinde Türkleştirişi temalar yansıtılmıştır. Gayrimüslim ilkokullarda Türkçe zorunlu hale getirilmiştir. Dini kurumlar dışındaki devlet lise ve üniversitelerinde öğretim dili Türkçe olmuş, fakat ortaokullarda mahalli diller de tamamen terkedilmemiştir. Böylece kamu devlet okullarında okumayanlar için devlet memuru olmak güç hale gelmekte, dolayısıyla Türk olmak cazip hale getirilmiştir. Bu yöntemle devlet eliyle eğitim kurumu tarafından kimlik inşası gerçekleştirilmiştir. Bu bir devrim olarak nitelendirilebilir, Türk 
Devrimi, bu düşünce üzerinde de tartışmalar olmuş, kimlik kazanımını eleştirip, Batı kimliği karşısında Türk kimliğini gösterme çabaları, yeniden Türk kimliğine dönme girişimleri eleştirilmiştir.

Batı zihniyeti farklılıkları ortadan kaldırmaya yönelik planlamalar yapması, bizim kendi toplumumuz için uygun bir zihniyet ya da düşünce ya da politika asla olamaz. Osmanlı Devleti, farklııkları koruyan bünyesi altında uzun yıllar zoraki değişimleri uğratmadan yaşamalarına imkân tanıyan bir imparatorluktur. Bu gurur duyulacak ve nesillere aktarılacak bir devlet politikası ve devlet zihniyetidir. Batı kimliği karşısında batının ifade ettiği Osmanlı Devleti'nde yaşayan bütün etnik grupları kapsayan, Türk ulusal kimliği onlar gibi zorlamalara dayanan politikalar benimsememelidir. Aslında hoşgörülü olmalı, toplumun tamamını kucakla ya bilmek onları zorlayarak kendi istediği çizgiye yerleştirmemekten gelir. Batı kimliği kendi içerisinde yüzyıllar boyunca etnik ve dini mezhepsel farklılıklar arasında kavgalar sergilenmiştir, bu kavgalar neticesinde toplumlar birbirlerinden ayrıştırılmıştır. Osmanlı Devleti'nde bu şekilde sadece kan bağı ya da dil bağı bulunmuyor diye büyük denli savaşlar gerçekleşmemiştir. Modern devlet, toplumu inşa edebilmek için kurumlar sayesinde müdahalede bulunur, farklılıkları ortadan kaldırmaya çalışarak devlet bünyesindeki herkesin birbirine benzemesini amaçlar. Yukarıda da ifade ettiğimiz gibi Modern devletler, toplumlarını inşa ederler. Cumhuriyetin ilk yıllarında da modern devlet olma yolunda bu şekilde politikalar izlenmiştir. Politikaların temelinde Türk ulusal kimliği yerleştirilmiş, resmi kimlik olarak yani üst kimlik olarak toplumun her kesimine benimsetilmek istenmiş, bunun içinde Anayasası'nda hiçbir fark gözetmeksizin kendini Türk hisseden Türk'tür maddesi yerleştirilmiştir. Batı kimliği karşısında Türk ulusal kimliği kendini bu şekilde tarihsel sürecini de gözler önüne çıkartarak koruyabilecek ne batıdan gelen milliyetçilik hareketlerinin karşısında bir çözüm olabileceğini, Cumhuriyet aydınları savunmuş halkı da bu yönde empoze, ederek dönüştürmeyi amaçlamıştır. Türk kimliği Batı kimliğinin karşısında güçlü bir kimlik olduğunu göstermek için birçok farklı etnik grubu bünyesinde toplayarak gücünü göstermeye çalışmıştır.

\section{3. İslâm Kimliği Karşısında Türk Kimliği}

Kimlik algısında dinin her zaman önemli bir payı mevcuttur. Din insanları kendisini tanımlamada etkili bir güçtür. Kimlik inşasında aşılması gereken bir engel mi yoksa destek mi konuları hep tartışılmıştır. Bu bölümde İslâm kimliği karşısında Türk kimliğini ele alarak, Osmanlı Devleti'nin son dönemlerde ortaya çıkan İslâmcılık ideolojisinin üst kimlik olma çabalarında neden başarılı olamadığını genel hatlarıyla ortaya koyarak, dönemin kimlik algısında İslâm kimliğinin yeri ve önemini açıklanacaktır. 
"İslâmcılık, Osmanlı coğrafyasında düşünsel ve siyasal bir hareket olarak modernleşmeci karakteriyle ortaya çıkmış bir akımdır. Diğer bir ifadeyle İslâmcılık, çağdaş Batı gelişmelerini Osmanlı toplum yapısına zarar vermeden getirmeyi amaçlayan Yeni Osmanlıların reform çabalarında ortaya çıkmış bir ideolojidir" (Karakaş, 2015: 184).

Klasik dönemi İslâmcıları arasında bir bütünlük görülmemektedir, farklııklar mevcuttur kendi içlerinde ayrışmışlardır.

Bu girişimlerin amacı Osmanlı Devleti'ni oluşturan halkların büyük çoğunluğu Müslüman olmalarından kaynaklanıyordu. İslâm dini bütünleşmeyi sağlayan bir aidiyet sunmaktaydı, bu nedenle devletin yönetici konumunda yer olan Osmanlı Devleti'nin padişahları halife statüsüne sahipti, bu da İslâm dünyası üzerinde mutlak güç kaynağı olacağı düşünülmekteydi. Osmanlı Devleti'nin elindeki bu dini liderlik gücü, yüz yıllar boyunca Batı da endişe ile karşılanmaktaydı. Batı da ortaya çıkan milliyetçi akımlar bu dini bütünlük üzerinde yıkıcı etkilere sebep olmuştur. Mezhep farklıııkları olsun, etnik farklılıklar olsun, İslâm kimliğinin, üst kimlik olmasında olumsuz etkilere neden olmuştur.

"Devletin belirlediğinin dışında kalan farklı dinsellik formlarının Cumhuriyeti önceleyen mevcudiyetinin 1923 sonrasında; devletle, dinî cemaatler arasındaki baştan beri var olan kutuplaşmada açığa çıkar" (Altunoğlu, 2009: 322).

Devlet işlerini, laiklik ilkesiyle dinden arındırıldı, bu oldukça, ideolojik bir karardır. 19. yüzyıl Osmanlı Devleti'nin toprak bütünlüğü içerisinde meydana gelen ayaklanmalara ve toprak kayıplarına, Batıdan gelen devletlere karşı kendilerine savunabilmek için belirli stratejiler geliştirmesi gerektirmiştir. 19. yüzyılda Osmanlı Devleti askeri, siyasi ve iktisadi olarak güç kaybetmiştir. Özellikle de Fransız İhtilali içinde barındırdığı dini, dışarıda bırakan devlet politikalarıyla milliyetçilik görüşleri Osmanlı Devleti için büyük tehdit oluşturmuştur. Avrupa'da meydana gelen sosyal hareketler ve sanayi devriminden sonra kurulan ulus devletler, Osmanlı Devleti'nin içyapısını zayıflatılmış ve Avrupa devletlerine karşı zafiyet doğurmuştur. Bu gelişmelerle beraber Osmanlı Devleti'nde ilan edilen Islahat Fermanı'yla Osmanlı Devleti'nin yeni bir dönemi başladığı anlaşılmaktadır. Osmanlı Devleti içerisinde yer alan Müslüman halkın gayrimüslimlere göre ikinci planda tutulması başta Namık Kemal, Ali Suavi ve Ziya Paşa başta olmak üzere birçok aydının İslâmi bir söyleme başvurmasına sebep olmuştur (Aytepe, 2016: 172). 
Batılılaşma yolunda devlet yöneticileri laiklik ilkesinin benimsenmesi konusunda karar verdiler. Bu sayede ülke sınırları içerisinde yaşayan bütün dini unsurlar devletin ötekileştirilemeyen vatandaşı olabileceği inancı doğurmak yani güven sağlayabilmekten kaynaklanıyordu. İslâmiyet'tin ikinci plana atılmasının asıl nedeni, Batı tarzı modernleşme çabaları geliyordu, o halde Batılılaşma girişimlerinin Osmanlı Devleti'nde ivme kazandığı Tanzimat Fermanı'nın okunuşundan itibaren incelemeye başlamalıyız. Ekonomik, askeri ve bilimsel olarak Osmanlı Devleti'nden daha üstün olmaları ve bu güçlerini İslâm dünyasına yönetmeleri İslâm dünyasının İslâm ideolojisi anlayışını yeniden sistemleştirme çabasına neden olmuştur. Dini değerlere verilen anlamlar yeniden gözden geçirilmiştir.

Şener Aktürk'ün günümüze uzanan üst, çatı kimlik anlayışının toplum nazarındaki bilincini eldeki veriler doğrultusunda açıklarsak şu ifadelere yer vermemiz gerekir. "Yüzde 99'u Müslüman olan Türkiye" söylemine rağmen sanırım ilk kimliğini Müslümanlık olarak veren yüzde 81'lik kesimdir tabi bu veriler Tahan Erdem'in önderliğinde KONDA araştırma şirketinin 2007 yılında yaptığı araştırma sonucundan yararlanarak, eklenmiştir. Toplumun yüzde $81^{\prime}$ in, kendini Türk olarak nitelendirirken geriye kalan 19'luk kesim daha kapsayıcı bir üst kimlik inşa etmek daha doğru olacağını söylemiştir, elbette bu oranlar Cumhuriyetin inşa sürecinde bir amaç doğrultusunda oluşturulmaya çalışılan Türk üst kimliğin 75-80 sene sonraki neticelerindendir. Alevilerin çoğunluğunun hem de Sünniler arasında "laik kesim" olarak bilinenlerin Müslümanlık etrafındaki bir ortak tasavvuru reddetmeleri intimali yüksektir (Aktürk, 2013: 275-276). Bu tartışmalar etnik köken üzerine yoğunlaştığı için üst kimlik bir etnik köken üstüne inşa edilemezdi, çünkü birden çok etnik köken sahibi bir toplumda bu hoş karşılanmayacaktır. Türkçülük etnik kökeni ifade etmeyen bir kavram olarak tanımlanmak istenilmiştir. Bu şekilde, çok kültürlü bir toplumun üst kimliği olabileceği düşünülmüştür. Türk üst kimlik olarak 1924 Anayasası'nda yer alan maddede "Türkiye'de din ve ırk ayırt edilmeksizin vatandaşlık bakımından herkese Türk denir" (Sabah, 2012'den akt. Aktürk, 2013:277).

1924 Anayasası'nda yer alan maddesiyle birlikte toplum yapısı; çok dilli, çok dinle, çok kültürlü, toplumun ortak siyasi kimliği olarak Türkçülük, 21. yüzyılda çağdaş bir kimlik olarak yeniden inşa edilmiştir. Türk kimliği tarihsel olarak çeşitli ırk, dil ve dinsel farklılıklara sahip insanın ortak kimliği olarak kullanılmıştır. Hristiyan Avrupalıların, Türk adını Osmanlılara verdiği bilinmektedir. Batılılar, Osmanlı sözcüğünü Türk Devleti'nin adı olarak algıladılar, o anlamda kullandılar. Kendisine imparatorluk kimliği arayan 
Osmanlılar ise, Türk, Türkmen varlığını, imparatorluğu oluşturan milletlerden sadece birisi olarak gördüler (Güvenç, 2008: 168).

Toplum kimlik arayışında yalnız etnik köken önemli değildir, Millet tanımı sadece gücünü kan bağından almaz, kan bağı kadar din bağıda önemlidir.

İslâm kimliğine sahip toplumların, en büyük öncüsü Osmanlı Devleti, modern Avrupa medeniyetinin İslâm dünyası aleyhinde oluşturdukları tehditlerin üstesinden gelebilmek için ancak modernleşmeleri gerekliliği algısı ve modernleşme koşullarına uyarak yeniden inşa sürecine girilmesi gerekliliği görüşü oluşmuştur. Bu inşa sürecinde dinin kılavuzluğunda gerçekleşen bir modernleşme ile mümkün olabileceğini düşünmüşlerdir. Sonuç olarak Avrupa'nın gerisine düşmelerinin nedenini İslâm'ın asli gayelerinden uzaklaşmalarını göstererek tekrar İslâm'ın özüne inerek yeniden kendilerini daha güçlü bir noktaya getireceklerini inancına sahiplerdir. Tekrardan Kur'an ve sünnete geri dönerek İçtihat kapısının açılmasını ve Cihat ruhun uyandırılması gece görüşü batının ürettiği bilgi teknoloji nesnel bir değer olarak kabul edilmiş medeniyetin alınmasında sakınca görülmemiştir. Daha sonraki süreçte Cumhuriyetin ilk yıllarında,

"Kemalistler, laikliği yani dinin devletten ayrılması ilkesini değil, devletçe denetlenen İslâm'ı getirdiler. İslâm'ı, reform programları ve devrimlerini, gerektiğinde Diyanet İşleri Başkanlığı tarafından meşrulaştıracak şekilde kullanmaya niyet ettiler" (Ahmad, 2006: 116).

Ulus devlet yolundaki din engeli bir şekilde kaldırılmış, toplumun tepkisi ortadan kaldırısın diye fetvalar verilmiş, devleti kontrol eden İslâm dini, devlet kontrolüne sokulmuş bunun için Diyanet işleri başkanlığı kurulmuştur. Diyanet işleri Bakanlığı tarafından, meşrulaştıracak şekilde kullanmaya niyet etiler. Bilgi ve bilim "hayatta en hakiki mürşit" olarak tanımlanmaya başlandı, şehir kadınları da bir modernleşme rejiminde bir yararlanmaya başladılar (Ahmad, 2006:116).

Türkiye'de üst kimlik algısında ortaya çıkan farklılaşmalar, toplumun kendi içerisinde ayrışmalara ve gerilimlere neden olmuştur. İslâm ve laiklik arasında ortaya çıkan gerilimler ve bu gerilimlerin en yoğun yaşandığı alan semboller ve kadınların giyim tarzı ya da kostümler alanında yaşanmıştır. Buna din ile modernleşme bağlamında yaşanan gerilim olarak örnek verebiliriz. Ortaya çıkan sorunlar İslâmcılar gibi yaşamsal farklılığa muhalefet unsurların etkinliğini arttırmıştır (Robins, 1996'den akt. Karakaş, 2013: 29). 
Okur, yazar oranının arttırılması için girişimler, harf inkılabının gerçekleşmesi ve devlet kadrolarında memur olunabilmesi için Latin harflerinin öğrenimi hızlanmış ve yaygınlaşmıştır. Şehirlerde yaşayan kadınlar, modernleşme den daha hızlı faydalanmış, iş hayatına ve eğitime daha kolay katılmışlardır. İslâm kimliği engellerinden bir diğeri olarak yukarıda Batıda ortaya çıkan milliyetçilik akımı olarak iki nedenden birisi göstermiştik, ulus devlete engel teşkil ettiği için İslâm kimliğini neden başarılı olamadığına değindik, şimdide milliyetçilik akımları, İslâm kimliği üzerine yaptıkları yıkıcı etkili açıklayalım.

Batı toplumunun kurtuluşu aradığı unsurlar ile bizimkiler tarih boyunca uzlaşamamıştır. Ziya Gökalp'ın ifadeleriyle açıklayacak olursak, dinimizi kültür içerisinde muhafaza edeceğiz, ama Batı medeniyetinin bilim ve teknolojisinden yararlanacağız. Bu sayede modern, bir devlet olabiliriz. İslâmi unsurlar bizim kültürümüzün özü, kültürel farklılıklar korunarak dinimizin korunacağı görüşü daha sonraları birçok eleştirilere uğramıştır. İslâm kimliği kapsayıcılık hayallerine ulaşamamasının temelinde de bu gelişmeler geliyordu, bu yüzden Türk kimliğinin karşısında İslâm kimliği daha irrasyonel karşılandı ve Müslüman olmalarına rağmen farklı etnik kökenler ya da mezhep farklılığı gibi durumlardan kaynaklı bütünleşme sağlanamamış, İslâm kimliği, üst kimlik olmada başarılı olamamıştır (Gülalp, 2003: 39).

\subsection{Toplum Karşısında Türk Kimliği}

Bu bölümde Cumhuriyet döneminde dayatmayla oluşturulan ulusal kimlik ve toplum üzerinde algılanış biçimini ele alınmıştır. Bu sayede Cumhuriyet dönemi kimlik inşasında, ulaşılmak istenilen gayenin nedenini, Osmanlı Devleti'nde Batılılaşma yavaş, kendiliğinden ilerlerken, Cumhuriyetin ilanı sonrası değişimin hız kazanma nedenleri, devlet yöneticilerin bu ideolojiye intiyaç duyma gereksinimleri iyi bir şekilde ortaya koymalıyız.

"Osmanlı'dan günümüze siyasal yapıyı etkileyen ve genel olarak da toplumsal yapı üzerinde belirleyici olan bir faktör olagelmiştir. Toplumların tarihsel süreç içerisinde yaşadıkları temel kırılma dönemleri, kimlik konusunda da değişikliklere yol açmıştır" (Karakaş, 2013: 1).

Cumhuriyet ile başlayan resmi kimlik inşası kapsamında, atılan politik adımlar ve dinin kontrol altında tutulma girişimleri, toplumun üzerine uygulanan baskıcı uygulamalarda, resmi kimliğin kabulünü güçleştiren unsurlar içerisinde önemli paya sahip olduğu söylenebilir (Altun, 2013: 50). 
Türkiye Cumhuriyeti'nin 1923'teki kuruluşundan itibaren etnik çeşitlilik konusunda anti-etnik bir rejim sürdürdü. Anti-etnik rejim uygulamalarının daha şiddetli olduğu Türkiye'de, bu rejim biçiminin idealtipine, asimilasyoncu bir anti-etnik rejimin tarihsel olarak atfedildiği Fransa'dan daha yakın olmuştur (Dündar, 2007'den akt. Aktürk, 2015: 19). Ulusal kimlik için gerekli olan koşullar, insanların kabulüne dayandırılarak, bu kabulün kolaylaşması için devlet idari kadroları, Anayasal üzerinde ellerinden gelebildiği kadarıyla kolaylık sağladıkları ifade edilmektedir. Osmanlı aydınları bu doğrultu üzerine görevlerini uygulayarak, halkı en az sorunla karşılaşacak şekilde değiştirmeye çalışmışlardır. Osmanlı Devleti'nden gelen geleneksel ideolojiler, modern, ulus devlet çıkarları doğrultusunda değişime uğramıştır (Şevkli, 2009: 26-27).

Türk ulusal kimliği kendi dayanakları olan milletleri bir bakıma benzeştirmeye yönelmiş, tevhit inancına sahip vatandaşların, ortak bileşenlerinden olan İslâm dinine yönelik idari kadronun tutumu, modernleşme için batılılaşma çabaları eleştirilmiştir (Karakaş, 2013: 13).

Ziya Gökalp gibi düşünürler, Emile Durkheim gibi dayanışmacı sosyologların etkisi altında, görüşler öne sürmüşlerdir. Bireyden ziyade toplum çıkarları gözetilmiş, toplum odak merkezinde olan sosyolojik tutum sergilenmiştir.

Cumhuriyet Aydınları, devlet ideolojisi olarak toplumu analiz etmiş devletin uluslaşma ve modernleşme çabaları doğrultusunda vazife üstlenmişlerdir. Dinin dışarda tutulmasının nedeni olarak batı tarzı modernleşme benimsenmesi gösterilebilir. Dinler ulus devlet anlayışı ile uyuşmazlar, dinsel kimlik, toplum için ortak kimlik olma konusunda yeterli değillerdir. Çünkü kimlik için gerekli koşullar vardır, İslâm kimliği için istenilen koşullar, öyle isteğe bağlı değiştirilemez, basite indirilemezdi, cumhuriyet döneminde seçilen resmi kimlik, herkesi kapsamak için, basit koşullar ileri sürmüştür. Bu koşullar, ortak dil, hissiyat, vatandaşlık bağı gibi gerçekleşmesi kolay koşullardır (Şevkli, 2009: 30).

Etnik kimliğin koşulları vardır, bu koşulların sayısı artabilir ama kısaca özellikler şu şekildedir. "Kolektif bir öze ad, ortak bir soy miti, paylaşılan tarihi anılar, ortak kültürü farklı kılan bir ya da birden daha fazla unsur, özel bir "yurt"la bağı, nüfusun önemli kesimleri arasında dayanışma duygusu" (Smith, 1991'den akt. Karakaş, 2015: 109). Bu aradan anlaşılacaktır ki tarihsel süreç kimlik için çok önemlidir.

Batı tarzı siyasetle tek tipleştirme politikası kurumlar tarafından uygulanarak farklılıkların ortadan kaldırma girişimleri içerisinde bulunulmuştur. Osmanlı Devleti'nde yaşayan farklı etnik köken sahibi 
milletler hem bir arada yaşanması istenmiş hem de birbirlerinden Osmanlı Devleti dönemindeki gibi farklılıkları korunması istenmemiştir. Devlet ideolojisi, resmi kimlik oluşturulması için bu doğrultuda hareket etmiş, Batı tarzı yenilikler yaparak, halkı değiştirip dönüştürmeye çalışmıştır. Çalışmanın bundan sonrasını yeni rejimin izlediği politikalar üzerinden ilerletelim. Ama bu tek tipleştirme etnik çeşitliliğin üzerine baskı uygulamıştır. Şener Aktürk bu konu hakkında şöyle söylemiştir:

"Ulus devlet için resmi kimlik söz konusudur ve Osmanlı Devleti'nde devlet anlayışı bunun için yeterli değildir. Bunun için geçmişe öfke duyulan sözler sarf edilmiş, geçmiş hatalarıyla anılıp, başarılı icraatları dillendirilmemiştir. Eski güçlü döneme geri dönme isteği aslında Batı'dan ileri olduğumuz zaman dilimini işaret ederek, nasıl olursa olsun, ama biz Batı gibi bilimde güçlenerek, modern, muasır bir ulus devleti olma bilinci ile söylenmiştir. Bunun için bilimsel ifadeler kullanılmış, bilim yeni rejimin en önemli kılavuzu olmuştur, tartışmaların kaynağı da burada başlamaktadır. Türkiye'deki bütün etnik unsurları Türk kökenli kabul etmenin bilimsel bir temeli yoktur" (Alakel, 2011: 14).

Resmi kimlik, ulus inşasında ortada sorun teşkil edebilecek unsurlar ya yok sayılmış ya da ortadan kaldırılmaya çalışılmıştır. Dinin bütünleşmeyi, kapsayıcılığı engellediği gerekçesiyle ortadan kaldırılması görüşü ile Anayasada yer alan resmi kimlik koşulları da Osmanlı Devleti'nden Cumhuriyet Türkiye'ne kalan etnik grupları da bir bakıma sınırlandırıyor, ötekileştirmiştir. Türklerin 16. yüzyıldan itibaren Avrupa'nın gerisinde kalmasının sebebi de budur diye yorumlamalar olmuştur. Cumhuriyet Aydınları bu sebeplerden dolayı toplumun kültürel değerlerinin özünü oluşturan, dini sembollere saldırmış, yeni rejim içerisinde dini unsurlar istenmemiştir. Toplum bu şekilde hızlandırılmış kimlik inşasında kendi kimlik algısında bir bunalıma girmiş ve din konusunda yapılan politikalar, toplumun bir gecede harf inkılabı ile cahil bırakılması, hatta kılık kıyafete bile yeni rejimin karışması tepki çekmiştir (Alakel, 2011: 18).

Toplum yapılan yenilikleri yadırgamış, kültürel pratiklerine karışılmasını kabul edememiştir. Toplum tek bir milletten, kültürden oluşmuyordu, rejimin hedefi bu farklılıklardan arındırılmış yeni bir toplum inşa etmekti, dinin sembollerin yerine pozitivist bilimsel sembollerin yer alması isteniliyordu, yapılan politikalar bunun açık göstergeleridir. Süreç içerisinde Türk kimliğinin kat etmiş olduğu yollar iyi bir şekilde ortaya konularak, cumhuriyet döneminin ilk yıllarında inşa edilen Türk kimliği daha iyi anlaşılacaktır. Bu çalışmada, cumhuriyet sonrasında Batı tarzı bir modernleşme girişimi neticesinde yapılan yenilikler toplumu karşısına alarak 
yani halka rağmen halkçılık politikası izlenerek toplum değiştirilip dönüştürülme girişimleri açıklanmıştır. Yeni rejim benimsediği ideoloji çerçevesinde, Batı tarzı bir toplum inşa etmek istediği anlaşılmıştır. Bu girişimlerin karşısında durabilecek cemaati yapıların ya da halkı isyana teşvik edecek dini örgütsel liderlerin yeni rejim tarafından tehdit algıladıkları görülmüştür. Cumhuriyet aydınlarının üst kimlik oluşturma da aldıkları vazifeler neticesinde yapmış oldukları çalışmalar toplumun yeniliklere karşı isyankâr tutumlarını ortadan kaldırmak yani Cumhuriyet Aydınları'nın görevi toplumla yeni rejim arasında tampon bölge görevi görmektir. Bu doğrultuda önderliğini Zìa Gökalp'in yaptığı düşünürler modernleşme girişimlerine teknolojik yönleriyle ele aldıklarını göstererek, dini motiflere toplumun kültürü içerisinde korunacağını savunmuştur. Elbette düşüncelerindeki kültür ve medeniyet ayrımı önemli olup yeni rejim ideolojisini de etkilemiştir. Batılılaşma, modernleşme, uluslaşma girişimlerinde toplum yetersiz görülüp, dönüştürülmeye çalışılmış, resmi kimlik olarak Türk kimliği dayatılarak, tek tipleştirilmeye toplum maruz bırakılmıştır. Bunun gerekli görülüp, ulus devlet şartlarından gerekli olarak algıladığı yeni rejimin ideolojisinin kaynağıydı.

\section{SONUÇ VE ÖNERİLER}

Orta Asya'dan Selçuklu'ya onlardan Osmanlı Devleti'ne Osmanlı Devleti'nden Türkiye Cumhuriyeti'ne bir değişim dönüşüm süreci vardır. $O$ değişim dönüşüm süreciyle birlikte toplumun sosyolojisi de değişmiştir. Tarihteki Türk devletleri iç ve dış etkiler neticesinde değişerek varlıklarını sürdürebildikleri noktaya kadar getirmişlerdir. Değişim elbette doğaldır. Cumhuriyet dönemin deki değişimin incelenmesi ulusumuz için önemlidir. Özellikle Cumhuriyet bir dönüştürme faaliyetidir. Aslında, bir toplumu topyekûn değiştirme dönüştürme faaliyetidir. Yukarıdan aşağıya, tepeden inme, baskıyla zorla kültürleme dediğimiz batılılaşma, modernleşme hareketidir. Cumhuriyet öncesinde iki yüz yıl geriye gidecek olursak modernleşme girişimlerini görürüz. Osmanlı Devleti'nde Tanzimat Fermanı, Islahat Fermanı, I. ve II. Meşrutiyetler bu modernleşme hareketlerinin göstergeleridir. Cumhuriyet inşa sürecinde izlenen yöntem, bu doğal olan modernleşme sürecini yapay bir hale getirmiştir. Modernleşmenin doğallığını bozmuştur. Bu doğallığın bozulmasının şöyle bir sonucu olmuştur, yönetim ile halk arasında çok ciddi gerilimler oluşmuş yani kopukluklar gerçekleşmiştir. Oysaki Cumhuriyet, yönetim yapısının temeli halk iradesine dayanmak demekti. Cumhuriyet rejimi halk iradesini, demokrasi dediğimiz gidişatı hedefliyor. Böyle hedefi olan bir kuruluş, nasıl böyle hatayla başlamış olması ilginçtir. Türk modernleşmesi dediğimiz süreç, aslında içselleştirilemeyen, ikinci el bir kıyafet tarzı bedene uymayan 
yönleri vardır. Yani Osmanlı Devleti'nden Türkiye Cumhuriyeti'ne kadar, doğal bir modernleşme süreci gerçekleşmiştir, bu dönemde sadece Osmanlı'da işleyen bir süreçte değildir. Modernleşme çabaları dünyanın birçok bölgesinde gözlemlenmekteydi. Avrupa'ya karşı Osmanlı Devleti, güçsüzlüğünün farkına varması ve güçleri dengelemek için siyasi ve idari gibi birçok alanlarda yenilikler yapmıştır. Hukuk alanında, maddi haklar alanında, teknoloji, sağlık, tıp alanında birçok modernleşmeye yönelik girişimler gerçekleştirmiştir. Her alanda Avrupa'nın gerisinde olmak Osmanlı Devleti'ni zor durumda bırakıyordu, yapılan yenilikler tekrar güçlü konuma gelmek içindir. Fakat bu yeniliklerle modernleşme çabaları halka çok fazla doğrudan yansımamıştır. Halka yansıyan etkileri elbette vardır. Örneğin Osmanlı Devleti'ni ayakta tutan en önemli iktisadi yapı tarımdır, tarımında gücünü aldığı tımar sistemi ortadan kaldırılıyor. Ama birçok alanda yapılan modernleşmelerin halka inememesi sadece bürokrasi ve saray etrafında gerçekleştirdiği modernleşmenin üst tarafta kaldığının göstergesidir.

Osmanlı Devleti'nde önemli olan halkın modernleşmesinde ziyade bürokratik yapının, zihin olarak modernleşmesiyle hazır duruma gelmesinden ibaretti. Askeri alanda yapılan yenilikler de askeri okullarda, Batı tarzı eğitim verilerek askeri kabiliyetlerinden çok bilimsel olarak gelişmeleri, askeri yapının güçlendirilebileceği düşüncesinden kaynaklanıyordu. Osmanlı Devleti, demokratikleşme çabasını aşamalı bir süreçle gerçekleştirilerek, modernleşmenin yapaylığı bozulmayacağı görüşü en belirgin özelliktir.

Bu durumda aydınların rolü de elbette vardır, marjinal aydınlar Tevfik Fikret gibi Abdullah Cevdet gibi tamamen batıcı, Ziya Gökalp gibi Yusuf Akçura gibi Türkçülüğün üst kimlik olarak gören düşünürler, Kimlik tartışmasının Türkçülüğün önemli isimlerindendir. Yusuf Akçura ve Ziya Gökalp bu ideolojiler üzerinde düşünceler ortaya koymuş ve kurtuluş için çareler sunmuşlardır. Cumhuriyetin ilk yıllarında yaşanan etnik ve kültürel farklar, önemli sorunlar arasında yer alıyordu. Ziya Gökalp, etnik grupları Müslüman ve Müslüman olmayan iki gruba ayırmıştır. Ziya Gökalp'e göre Türk ulusu sadede Türkçe konuşan Müslümanlardan oluşmaktaydı, cumhuriyet ideolojisiyle birlikte Türk olmak için Türkçe konuşmak ve vatandaş olmak yeterli görülmüş, bu durum Türk kimliği inşası için kendi birtakım görüşlerden vaz geçme anlamına gelmektedir. Yusuf Akçura' Türkçülüğü hem Osmanlı Devleti'nin hem de Orta Asya için bir siyasi çözüm olarak görmüştür. Elbette Osmanlı Devleti'nin son döneminde kimlik konusu üzerinde birçok tartışma yaşanmıştır. Tartışmalar içerisinde bazı düşünürler batının kültürünü alalım ama medeniyetini almayalım, ya da medeniyetini teknolojisini alsak kültüründe almış oluyoruz, dolayısıyla hiçbirini 
almayalım, başka düşünürler ise kurtuluş için başka çözüm yolu yok hepsini alalım şeklinde görüşler ortaya çıkmıştır.

Osmanlı Devleti'nde meydana gelen iç çekişmeler, yıkılışını hızlandırmış, özellikle askeri bir darbe olarak 1908 tarihinde Sultan II. Abdülhamit'in tahtan indirilmesiyle, İttihattı Terakki ile Birinci Dünya Savaşına girmemiz, Osmanlı Devleti'nin yıkılışını hızlandırmıştır. Batı tarzı siyaset, benimseyen ve aydın olarak nitelendirilen bürokrat kesim düşünürler. Kimlik konusunda kendi özümüz içindeki cevher yerine, yüzlerini batıya dönmüş ve onların yapmaya çalıştığı ikilemleri, içimizde gerçekleştirmişlerdir. Modernleşme ile başlayan kimlik algısı, Cumhuriyet Türkiye'sinin ilk yıllarında, hızlı bir şekilde değişmiş, kurucu kadronun, hedeflenen batıcı, modern, ulus-devlet modeli, Osmanlı Devleti'nden geriye kalan, topraklar üzerinde bir homojen, etnik farklılıkların yok sayan Türk ulusal kimliği olarak dayatılmıştır. Ulus-devlet için gerekli görülen ihtiyaçlar sorgusuz kabul edilmiş, engel teşkil edilecek hususlar üzerine gidilmiştir. Kimlikler kolay değişmeyen özelliklere sahiptir. Her ne kadar iktidarlar dayatma ile netice alabileceklerini düşünse de içselleştirilemez. Yanı şartlar konuşulmaya müsait olduğu ilk anda, patlak verir. Modern güçlü bir devlet ola bilmek için birliktelik elbette önemlidir, ama bu birliktelik üsten inme, dayatma ile herkes, tek tipleştirilerek sağlanabilecek gibi kolay bir durum değildir. Batı devletleri kendi içerisinde homojenleşme girişimlerini zaten başaramamıştır. Osmanlı Devleti yüz yıllar boyunca evrensel bir güç olmuş ve içerisindeki farklılıklar buna engel olmamıştır. Kurtuluş için aranılan çözüm yolları, geçmişimize bakılarak aranmalıydı, Ziya Gökalp'in yapmış olduğu hars, medeniyet ayrımı aslında yanlış bir formüldür. Ziya Gökalp’ın söylemleri, Cumhuriyetin kurucu ideolojisinin topluma yönelik dayatmalarının, toplum nezdinde sindirilebilmesi için batılılaşmaya meşruluk arayışıdır. Cumhuriyet inşa sürecinde Türk kimliğinin, ideolojik görüşlere temel kullanılması ve diğer kimliklerin üzerine çıkarılması, bununda ulus devlet için gerekli olan resmi kimlik ihtiyacından kaynaklanması, Türk kimliğini mahiyetini zedelemiştir. Tek millet o millet içerisindeki bütün farklılıkların yok edileceği anlamına gelmez. Birlik olmak ile tek tipleştirmek arasında farklar vardır. Birlik içerisinde çoklukları barındırır. Türkiye Cumhuriyeti de tıpkı diğer ulus devletler gibi bütün farklılıklar tek kimlikte toplanmaya çalışıldı ve Türk ulusal kimliği doğmuştur. Türk kimliği üzerinden ulus tanımı yapılmıştır.

1924 Anayasası sonrası, Türkiye de bütün farklılıkları etnik yerli kimliklerin Türkleştirilmesi için meclis kararlar almış ve idari uygulamalar gerçekleştirildi ve üst kimlik olarak Türk milleti kurgulanmıştır. Ulusal olarak inşa edilen kimlik etnik kimliğe indirilemez, Türk ulusal kimliği üzerine, etnik 
kimlik olmasından dolayı eleştiriler gelmiş bir türlü, etnik, ırksal zihniyetinden kurtulamadığından dolayı üst kimlik görülemediği görüşleri yüz yıldır tartışılmaktadır. Türk milleti, Kürt, Laz, Çerkez, Boşnak bütün etnik çeşitliliğimizden mi oluşmuştur? Yoksa kökleri orta Asya ya dayanan Türkmenlerden mi oluşur?

Eğer ilk sorunun cevabı evetse, o zaman, 1924 öncesi Türklükle ilgili pek bir şey söylemek doğru olamaz, çünkü Türk milleti eğer 1924'te Atatürk'ün dediği gibi cumhuriyeti kuran milletleri kapsıyorsa, tanım yeniden yapılandırılmış bir kimliği işaret eder ve Türk milleti dendiğinde akla, soydaş Türk devletleri yerine, Türkiye Cumhuriyeti'nde varını yoğunu vererek savaşan milletler gelmelidir. Toplumumuzun hiçbir zaman Türklükle bir sorunu olmamıştır. Cumhuriyetin ilanı ile hızlanan batılılaşma çabaları ve resmi kimliği tehdit olabilecek, diğer etnik, dini ve kültürel kimliklere karşı, sergilenen sindirme politikaları neticesinde, Türk kimliği ve diğer etnik kimlikler arasında gerilimler meydana gelmiştir. Dönemin güçlü ideolojisine karşı, toplum içinde yükselen karşıt görüşler elbette olmuştur, ama bu geniş kitlelere ulaşamamıştır. Sonuç olarak, modernleşme yanlış anlaşılan, yanlış yorumlanan bir çözüm yoludur. Modern bir devlet için modern bir toplum, kısa bir sürede, başka bir toplumlardan kopya çekilerek inşa edilemez, bunun neticeleri kaosu doğurur. Halk içselleştiremediği bir durumdan rahatsızığını elbet şartların uygun olduğu dönemde daha yüksek sesle ifade edecektir. Türk milleti olarak ortaya atılan büyük söylem; üst kimlik, ulusal kimlik olmak yerine, daha etnik kimlik bilinci göstermiştir. Günümüzde hala yüz sene öncesinin kimlik tartışmaları yaşanmaktadır, din ile devlet işlerinin arasındaki ilişki düzeyleri günümüze kadar süren bir tartışmadır. Andımızın kaldırılması Avrupa Birliğine girebilmemiz için, etnik kimliklere yönelik bir hoşgörü niyeti ile atılan önemli bir adımdır.

Alanında en usta marangoz tarafından kesilip şekillenmiş, ince ince işlenmiş ve üzerine maddi manevi paha biçilemez eşyalar koyulduğunda devrilmeyen, gıcırdamayan bir ahşap masa gibi Türk kimliği de diğer kimlikleri taşıyabildiğinde ve bu durum yerel etnik kimlikler tarafından içselleştirildiğinde, işte o zaman Türk kimliği, ulusal, kapsayıcı bir üst kimlik olmayı başaracaktır. İnsanların bir arada huzurlu ve mutlu yaşaması düşünüldüğü kadar zor değil, istersek başarabiliriz, tarihimiz bunun en büyük kanıtıdır.

\section{KAYNAKÇA}

Ahmad, F. (2006). Bir Kimlik Peşinde Türkiye. (Çev.). S. C. Karadeli. İstanbul: İstanbul Bilgi Üniversitesi. 
Aktürk, Ş. (2013). Türkiye'nin Kimlikleri Din, Dil, Etnisite, Milliyet, Devlet ve Medeniyet. (Dü.). M. A. Memmi. İstanbul: Etkileşim.

Aktürk, Ş. (2015). Almanya, Rusya ve Türkiye'de Etnisite Rejimleri ve Milliyet. İstanbul: İstanbul Bilgi Üniversitesi.

Alakel, M. (2011). İlk Dönem Cumhuriyet Türkiye'si Ulus İnşası Sürecinde Milliyetçilik ve Sivil-Etnik İkilemine Dair Teorik Tartışmalar. Gazi Akademik Bakış Dergisi 5, 1-30.

Altun, N. (2013). Modern Türkiye'de Kimlik: Kürt Kimliğinden Kürt

Sorununa. Akademik İncelemeler Dergisi (AID) 8(2), 45-67.

Altunoğlu, M. (2009). "Kimlik"in Modern İnşası, Kimlik Politikaları ve Türkiye'de Kimlik Tartışmaları. (Doktora Tezi). Erişim Adresi: https://dergipark.org.tr/tr/pub/nkusbmyo/issue/49954/618214

Arslantürk, Z. \& Amman, M. T. (2013). Sosyoloji; Kavramlar, Kurumlar, Süreçler, Teoriler. İstanbul: Çamlıca.

Avcıoğlu, G. Ş. (2011). Yapısal Kimlikten Seçimlik Kimliğe. Uluslararası İnsan Bilimleri Dergisi 8(2), 359-370.

Aydoğdu, H. (2004). Modern Kimlikte Öznenin Ölümü. Atatürk Üniversitesi Kazım Karabekir Eğitim Fakültesi Dergisi 10, 115-147.

Aytepe, M. (2016). Doğuşundan Günümüze İslâmcılıgın Türkiye Seyri. Muş Alpaslan Üniversitesi Sosyal Bilimler Dergisi 4(1), 170-200.

Bakacak, A. (2018). XX. Yüzyıl Başlarında Osmanlı Devleti. (Dü.). T. F. Ertan içinde, Başlangıçtan Günümüze Türkiye Cumhuriyeti Tarihi (s. 39-69). Ankara: Siyasal Kitapevi.

Dalbay, R. S. (2018). Kimlik ve Toplumsal Kimlik Kavramı. Süleyman Demirel Üniversitesi Sosyal Bilimler Enstitüsü Dergisi 31, 161-176.

Dalbay, R. S. \& Avcı, N. (2018). Kimlik İnşasına İlişkin Temel Yaklaşımlar ve Bu Yaklaşımların Türkiye'ye Yansımaları. Süleyman Demirel Üniversitesi İktisadi ve İdari Bilimler Fakültesi Dergisi 23(1), 17-39.

Gülalp, H. (2003). Kimlikler Siyaseti: Türkiye'de Siyasal İslâm'ın Temelleri. İstanbul: Metis.

Güllüpınar, F. (2012). Türkiye'de Eğitim Kurumu ve Sorunları. Z. Sungur (Dü.). içinde Türkiyenin Sosyal Yapısı (s. 84-115). Eskişehir: Anadolu Üniversitesi Açıöğretim.

Güvenç, B. (1993). Türk Kimliği. Ankara: Kültür Bakanlığı.

Güvenç, B. (2008). Türk Kimliği. İstanbul: Boyut.

İnanç, H. (2005). AB'ye Entegrasyon Sürecinde Türkiyenin Kimlikler Problemi. Ankara: Adres. 
İnceoğlu, E. (2009). Türkiye'de Siyasal İslâmcılığın Evrimi. (Yayınlanmış Yüksek Lisans Tezi). Ankara Üniversitesi, Sosyal Bilimler Enstitüsü, Ankara.

Kafesoğlu, İ. (1991). Türk Milli Kültürü. İstanbul: Bogaziçi.

Karakaş, M. (2007). Türk Ulusçulugunun İnşası. Ankara: Elips.

Karakaş, M. (2013). Türkiye'nin Kimlikler Siyaseti ve Sosyolojisi. Akademik İncelemeler Dergisi(AID) 8(2), 1-44.

Karakaş, M. (2015). Modernlik Küreselleşme ve Kimliklerin Evreni. İstanbul: Küre.

Kaçmazoğlu, H. B. (2015). Türk Sosyoloji Tarihi-II, II. Meşrutiyet'ten Cumhuriyet'e. İstanbul: Doğu Kitapevi.

Mardin, Ş. (1995). Türk Modernleşmesi. İstanbul: İletişim.

Şevkli, S. (2009). Resmi Söylemden Kültürel Kimliğe Türkiye'de Seküler Milliyetçilik. (Yüksek Lisans Tezi). YÖK Ulusal Tez Merkezi. 254598.

Tekin, N. M. (2013). Avrupa'da Ortak Kimlik Arayışı ve Bu Arayışın Türk Birliğini Sağlaması. Uluslararası Sosyal Araştırma Dergisi, 540-560.

Türk Dil Kurumu. (TDK) Güncel Türkçe Sözlük içinde Erişim Adresi: www.tdk.gov.tr Erişim Tarihi: 06.03.2020.

Türk, R. (2015). Türkiye' Siyasal İslâmın Örğütlenme Faliyetleri. Akademik Sayfa | 680 Hassasiyet Dergisi 2(5), 99-131.

GENIŞ̧LETİLİ̧̧ ÖZET: Kimlik konusunun kapsamı çok geniştir. Türk kimliği, milli kimlik, resmi kimlik ve kimlik dönüşümü üzerine birçok araştırma yapılmıştır. İnsanoğlu tarihsel süreçte nereden geldiğini ve nereye gideceğini, yaşadığı toplumda kendisini nerede konumlandırdığını ve kim olduğunu tarih boyunca sorgulamıştır. İnsanın yaratıış̧ gereği sosyalleşme ihtiyacı olan bir varlık olduğundan, insan kendisini tanımlamak için yaşadığı topluluğun içinde bir bağ kurabilmek için kimliğini belirlemek istemektedir. Diğer toplumlardan onları ayıran özellikleri, farklılıkları neticesinde diğer toplumlardan ayrışmayı, yaşadığı toplum içindeki; kültür, yaşam tarzları, gelenek görenek uyumları gibi benzer özelliklere göre bütünleşmeye itmiştir. Çalışmanın konusunu; Türk ulusal kimliğinin Türkiye Cumhuriyeti inşa sürecinde, 1839 Tanzimat Fermanıyla başlayıp, Cumhuriyetin ilanı 1923 ve Atatürk'ün vefatına kadar süren, ilke ve inkılapların kabulüne kadar geçen zaman diliminde içerdiği anlamlarının sosyo-politik bağlamlarıyla ele alınması oluşturmaktadır. Osmanlı Devleti'nin de ve üzerine inşa edilen Türkiye Cumhuriyetin de ortaya çıkan ideolojiler, kimlik anlayışları, toplumsal değişim ve benimsetilen, benimsetilmeye çalışılan üst kimlik algısı, toplumda bu kimliklerin nasıl algılandıkları ve bu kimliklerin neler oldukları incelenmektedir. Çalışmanın önemini, Türkiye Cumhuriyeti'nin kuruluş süreci öncesinden başlayan ve kuruluş sonrası devam eden kimlik tartışmaları üzerine yoğunlaşarak, dönemin sosyal, siyasal ve ekonomik şartları dahilinde, araştırma gerçekleştirilmiştir. Bu çalışmayla birlikte Tanzimat Fermanı'yla başlayan modernleşme girişimlerinin toplumda 
algılanması, kimlik anlayışında değişimler, cumhuriyetin kuruluşundan sonra devam eden modernleşme, toplumda değişim ve dönüşüm konusunu ele alması yönünden önem arz eder. Bu alanda daha fazla çalışmalar yapılmasıyla kendi kimliğimizi çok daha iyi anlayabilmemiz için gereklidir. Türk ulusal kimliği konusunu daha dar kapsamlı ele almış olsak da her bölümde işlenen üst kimlik algısı kendi içinde ayrı bir önem arz eder. Ulus-devlet inşa sürecinde, resmi kimlik oluşturma çabaları ve bu doğrultuda geleneksel ideolojilerin reddi ortaya çıkartılarak, kimliğin dönüşümü incelenmiştir. Araştırma, 1839'da Tanzimat Fermanıyla başlayan batılılaşma çabaları, demokratikleşme girişimleri ve kimlik algısı üzerine etkilerinden, Atatürk'ün ölümü 1938'e kadar geçen süreç kapsamında ele alınan dönem sınırlandırılmıştır. Dönemin karakteristik özellikleri dışına çıkılmadan kimlik konusunu incelenmektedir. Çalışmanın yöntemi için "Dokümantasyon Metodu" seçilmiş, konular bu yöntem sayesinde araştırılmıştır. Kısaca konular; Türkiye Cumhuriyeti'nin kuruluş sürecinde üst kimlik inşası, inşa sürecine yardımcı batılılaşma çabaları, İslâm kimliğinin devlet için ideal kimlik görülmemesi, Osmanlı Devleti'ni şekillendiren, kontrol altına alan İslâm dini, yeni rejimle birlikte devlet kontrolü altına alınması, toplumun algısal kimliğindeki değişimler ve Cumhuriyet ideolojisinin benimsetmek istediği kimlik görüşü geniş kapsamlı incelenmiştir. Cumhuriyet sonrası Atatürk'ün 1923'ten 1938'e kadar ve ondan sonraki tek partili yıllarda titizlikle incelenmiştir. Bu çalışma 1839'dan 1923'e kadar toplumsal kimlik algısının değişim dönüşümünü sadece 1923'ten sonrasını değil Osmanlı Devleti'nin son dönemlerindeki modernleşme, batııılaşma, toplumsal kimlik algısının üst kimlik kabullerini ortaya çıkarılması amacıyla böyle bir çalışma intiyaç duyulmuştur. Çalışmada Osmanlı Devleti'nin son dönemlerinde ortaya çıkan ideolojilerin tek tek ele alınarak Türkiye Cumhuriyeti'nin ilanıyla beraber fikir ayrışmaları, değişen kimlik, devlet eliyle ortaya konan Türk ulusal kimliği, çeşitli kaynaklardan faydalanarak ele alınmış, Türk ulusal kimliğinin toplum ve dünya üzerindeki yeri ve öneminin, amacının ne olduğu ortaya konulmasına çalışılmıştır. Sonuç olarak Osmanlı Devleti'nde Tanzimat Fermanı, Islahat Fermanı, I. ve II. Meşrutiyetler modernleşme hareketlerinin Osmanlı Devleti'ndeki göstergeleridir. Cumhuriyet inşa sürecinde izlenen yöntem, bu doğal olan modernleşme sürecini yapay bir hale getirmiştir. Modernleşmenin doğallığını bozmuştur. Bu doğallığın bozulmasının şöyle bir sonucu olmuştur, yönetim ile halk arasında çok ciddi gerilimler oluşmuş yani kopukluklar gerçekleşmiştir. Oysaki Cumhuriyet, yönetim yapısının temeli halk iradesine dayanmak demekti. Cumhuriyet rejimi halk iradesini, demokrasi dediğimiz gidişatı hedefliyor. Böyle hedefi olan bir kuruluş, nasıl böyle hatayla başlamış olması ilginçtir. Cumhuriyet inşa sürecinde Türk kimliğinin, ideolojik görüşlere temel kullanılması ve diğer kimliklerin üzerine çıkarılması, bununda ulus devlet için gerekli olan resmi kimlik intiyacından kaynaklanması, Türk kimliğini mahiyetini zedelemiştir. Tek millet o millet içerisindeki bütün farklılıkların yok edileceği anlamına gelmez. Birlik olmak ile tek tipleştirmek arasında farklar vardır. Birlik içerisinde çoklukları barındırır. Türkiye Cumhuriyeti de tıpkı diğer ulus devletler gibi bütün farklılıklar tek kimlikte toplanmaya çalışıldı ve Türk ulusal kimliği doğmuştur. Türk kimliği üzerinden ulus tanımı yapılmıştır. Modernleşme yanlış anlaşılan, yanlış yorumlanan bir çözüm 
yoludur. Modern bir devlet için modern bir toplum, kısa bir sürede, başka bir toplumlardan kopya çekilerek inşa edilemez, bunun neticeleri kaosu doğurur. Halk içselleştiremediği bir durumdan rahatsızlığını elbet şartların uygun olduğu dönemde daha yüksek sesle ifade edecektir. Türk milleti olarak ortaya atılan büyük söylem; üst kimlik, ulusal kimlik olmak yerine, daha etnik kimlik bilinci göstermiştir. Günümüzde hala yüz sene öncesinin kimlik tartışmaları yaşanmaktadır, din ile devlet işlerinin arasındaki ilişki düzeyleri günümüze kadar süren bir tartışmadır. Andımızın kaldırıması Avrupa Birliğine girebilmemiz için, etnik kimliklere yönelik bir hoşgörü niyetiyle atılan önemli bir adımdır.

EXTENDED SUMMARY: The issue of identity is very wide in scope. Many studies have been conducted on Turkish identity, national identity, official identity and identity transformation. Throughout history, human beings have questioned where they came from and where they will go, where they position themselves in the society they live in, and who they are. Since the human being is a creature that needs socialization, he wants to determine his identity in order to establish a bond within the community he lives in to define himself. The characteristics that distinguish them from other societies, the separation from other societies as a result of their differences, in the society they live in; culture, lifestyles, traditions and traditions. The subject of the study; In the process of building the Turkish Republic of Turkey national identity, in 1839, starting with the Tanzimat, which lasted until the death of the proclamation of the Republic of 1923 and of the meanings it contains principles and the lapse of time until the adoption of the reforms constitute addressing the socio-political context. The Ottoman Empire as well and built the Republic of Turkey from emerging ideologies on identity understandings, social change and are adopted, studied the upper sense of identity to assimilate in society, how they perceived these identities and examined that what these identities. The importance of the study process began before the establishment of the Republic of Turkey and by focusing on the ongoing debates over identity after the establishment period of social, political and economic conditions within the research was conducted. With this work, it is important for the perception of the modernization attempts that started with the Tanzimat Edict in the society, the changes in the understanding of identity, the modernization that continues after the establishment of the republic, the change and transformation in the society. It is necessary for us to understand our own identity much better with further studies in this field. Even though we have dealt with the issue of Turkish national identity in a narrower scope, the perception of upper identity in each section has a special importance in itself. In the nation-state building process, the efforts to form an official identity and the rejection of traditional ideologies in this direction have been revealed, and the transformation of identity has been examined. The research has been limited to the period from the westernization efforts, democratization attempts and the effects on identity perception that started with the Tanzimat Edict in 1839, until the death of Atatürk in 1938. The issue of identity is examined without going beyond the characteristic features of the period. "Documentation Method" was chosen for the method of the study, and 
the subjects were researched by means of this method. Brief topics; The establishment of upper construction of identity in the process of the Republic of Turkey, helping to build the process of westernization efforts, absence ideal identity for the state of Islamic identity, shaping the Ottoman Empire controlled area of Islam, is under state control with the new regime, the change in society's perceptual identity and the Republic The identity view that the ideology wants to adopt has been studied extensively. After the Republic, Atatürk was carefully studied from 1923 to 1938 and in the one-party years after him. This study was needed in order to reveal the transformation of social identity perception from 1839 to 1923 , not only after 1923, but also the modernization, westernization, and upper identity acceptance of the social identity perception in the last period of the Ottoman Empire. The study examined one of the ideology that emerged in the late Ottoman period, one idea divisions together with the declaration of the Republic of Turkey, changing identity, state-laid Turkish national identity, discussed benefiting from a variety of sources, the place of the Turkish national identity on society and the world and the importance of It has been tried to reveal what its purpose is. As a result, in the Ottoman Empire, Tanzimat Edict, Islahat Edict, I. and II. Constitutional Monarchy are the indicators of modernization movements in the Ottoman Empire. The method followed in the republic building process made this natural modernization process artificial. It has disturbed the naturalness of modernization. This has been a result of the deterioration of naturalness, there have been very serious tensions between the administration and the people, that is, ruptures have occurred. However, the foundation of the Republic, the administrative structure was based on the will of the people. The republican regime targets the will of the people, the course we call democracy. It is interesting how an organization with such a target got started with such error. The fact that Turkish identity was used as a basis for ideological views and elevated above other identities during the process of republic building, stemming from the need for official identity for the nation state, damaged the nature of the Turkish identity. One nation does not mean that all differences within that nation will be eradicated. There are differences between being unity and uniformity. It contains the multitudes in the unity. All differences just like every other nation states such as the Republic of Turkey has tried to gather in a single identity and Turkish national identity was born. The definition of nation was made over the Turkish identity. Modernization is a misunderstood, misinterpreted solution. For a modern state, a modern society cannot be built in a short time by copying from other societies, the consequences of this create chaos. The public will express their discomfort from a situation they cannot internalize louder when the conditions are suitable. The great discourse put forward as the Turkish nation; Supreme identity showed more ethnic identity awareness than national identity. Today, there are still debates about identity a hundred years ago, and the level of relationship between religion and state affairs is a debate that continues until today. The abolition of our oath is an important step taken with the intention of tolerating ethnic identities in order to enter the European Union. 